\title{
Antibody Engineering at the Millennium
}

BioTechniques 29:128-145 (July 2000)

\author{
Jorge V. Gavilondo ${ }^{1}$ and \\ James W. Larrick ${ }^{2}$ \\ ${ }^{1}$ Center for Genetic Engineering \\ and Biotechnology, Havana, \\ Cuba and ${ }^{2}$ Palo Alto Institute of \\ Molecular Medicine, Mountain \\ View, CA, USA
}

\section{INTRODUCTION}

The first documented attempts to use animal antibodies to treat infectious diseases in humans are over a century old $(24,160)$. In the 1930s and 1940s, this novel kind of serum therapy was largely replaced by antibiotics such as the sulfonamides and penicillin. The associated toxicity of serum sickness also contributed to the decline of therapeutic horse and rabbit antisera (25). Human antisera and polyclonal immunoglobulin preparations were better tolerated; however, their limitations include lotto-lot variation, low content of specific antibodies (161) and potential contamination by infectious agents such as hepatitis viruses and HIV $(50,155)$.

The discovery and diffusion of monoclonal antibody (MAb) technology (89) in the late 1970s and early 1980s opened a new era in human therapeutics. The economic promise of MAbs was said to be limitless. In fact, MAbs could be selected with exquisite specificity. They could orchestrate various components of the immune system such as antibody-dependent cell cytotoxicity (ADCC) and complement, and they showed a high biological half-life in blood and tissues, rendering them effective for prophylactic use. The toxicity of infused MAbs was expected to be low because of their biological nature. Hence, such magic bullets were enthusiastically hailed in press accounts at the time as the solution to cancer. This ideal was boosted by the successful clinical results of mouse antiidiotypic MAbs in the treatment of lymphomas and leukemias (96) and by FDA approval in 1986 of the OKT3 anti-CD3 mouse MAb for acute renal transplant rejection (152).

However, this excess of optimism was soon followed by a dark age of skepticism that was motivated by ad- verse clinical and laboratory findings. When rodent MAbs were used therapeutically, a human antimurine antibody response (HAMA) developed in up to $50 \%$ of treated patients (84). Effector functions of mouse antibodies also proved to be less efficient in the human context. Their biological halflife was shorter when compared to human immunoglobulins, factors that greatly limited their usefulness. These risks and limitations could theoretically be overcome with MAbs of human origin (156), but despite intense efforts $(12,20,43,60)$, human MAbs from hybridomas and lymphocyte cell lines have proven too difficult to generate easily. Finally and perhaps most importantly, the failures of clinical trials of the anti-LPS mouse IgM E5 MAb from Xoma (Berkeley, CA, USA) (completed between 1992 and 1993) and the human IgM HA-1A from Stanford/Centocor (Leiden, The Netherlands) for septic shock (27) combined to dampen interest in MAbs as therapeutic drugs.

The spell was broken in 1994 when the FDA approved the antiplatelet mouse MAb ReoPro ${ }^{\mathrm{TM}}$ (Centocor) to treat the complications of angioplasty (54). This modest success was followed by FDA approval of six other engineered antibodies between 1997 and 1999-Rituximab ${ }^{\mathrm{TM}}$, a mouse/human chimeric anti-CD20 antibody (IDEC/ Genentech, San Francisco, CA, USA) to combat follicular non-Hodgkin's B cell lymphoma (59); Zenapax ${ }^{\mathrm{TM}}$, a humanized anti-IL2 TAC receptor antibody developed by Protein Design Labs/Hoffmann-La Roche (Basel, Switzerland) to control the acute rejection of kidney transplantion (46); Simulect $^{\mathrm{TM}}$, a chimeric anti-CD25 antibody from Novartis (Basel, Switzerland) for allograft rejection (115); Herceptin ${ }^{\mathrm{TM}}$, the first antibody-based drug for adjuvant therapy of 
a solid tumor (breast cancer) advanced by Genentech (162); Remicade ${ }^{\mathrm{TM}}$, from Centocor, an anti-TNF antibody indicated for Crohn's disease (132) and rheumatoid arthritis (100); and Synagis ${ }^{\mathrm{TM}}$, from Medimmune (Gaithersburg, MD, USA), a humanized anti-respiratory syncytial virus antibody for the treatment of infections in children (144).

Antibodies now account for the single largest group of biotechnology-derived molecules in clinical trials $(39,49$, 143) and have a prospective market of several billion dollars. According to the Pharmaceutical Research and Manufacturers of America (http://www. phrma.org), $20 \%$ of all biopharmaceuticals in clinical development in 1998 were antibody products. Some commissioned global surveys indicate that 264 companies are working on 701 therapeutic antibodies, 220 of which are in clinical trials. [For a related article, visit http://www.biospace.com.]

The resurgence of interest in antibody-based therapeutics at the millennium is a direct consequence of the introduction of genetically engineered immunoglobulins $(13,33,36,150)$ and the refinement of targets for antibody therapy. MAbs or their recombinant derivatives are being evaluated for the prophylaxis, therapy and control of allergic and autoimmune diseases; complications of angioplasty; sepsis; a variety of inflammatory diseases; many viral and bacterial infections; organ transplant rejection; and solid and hematological tumors. Several antibody molecules, now in advanced phase III trials [for colon cancer and asthma (110) and allergic rhinitis (79)], are expected on the market quite soon. A table is available in pdf format that presents an extended sample of ongoing clinical trials and illustrates the diversity of antibody targets. [Please go to the "Online Journal" section of the site (www.biotechniques.com) and search by the title of this article.]

This article is an updated and comprehensive review of the variety of exciting new molecules and technologies that have been produced by antibody engineering, a field that has experienced an extraordinary explosion and diversification in only a few years (Table 1). Relevant Internet links and patent references can be found in the ongoing text, and Table 2 lists Web sites that cover antibodies.

\section{CLONING OF ANTIBODY V-REGION GENES FOR RECOMBINANT ANTIBODIES}

The most important immunoglobulin DNA sequences to be cloned and manipulated for antibody engineering to proceed are the variable $(\mathrm{V})$ domain genes of both heavy $(\mathrm{H})$ and light $(\mathrm{L})$ chains that determine the complete functional structure of the antigen-binding site. The initial cloning of immunoglobulin genes started more than 15 years ago with the construction of libraries of genomic DNA (113) from donor cells (hybridomas, B-lymphocytes or B-tumor cell lines). This procedure was slow and tedious because it was necessary to identify clones containing rearranged, complete antibody genes. Introns, existing between the signal peptide, $\mathrm{V}$ and constant (C) domain-encoding sequences, imposed additional technical difficulties. Although the construction of antibody cDNA libraries was an important step forward, it was the discovery of PCR (114) and its application to the field $(93,94,123)$ that greatly simplified the cloning of $\mathrm{V}$ region genes and set the stage for extraordinary advances in antibody engineering.

To amplify the $\mathrm{V}_{\mathrm{L}}$ and $\mathrm{V}_{\mathrm{H}}$ immunoglobulin regions by PCR, cDNA is fabricated by reverse transcription from RNA extracted from hybridomas or B-lymphocytes. With the amplification of the desired mature V-region genes, this step avoids completely the interference by unrearranged genes and introns. The PCR primer sets are designed on the basis of conserved flanking base sequences that exist at the beginning of $\mathrm{V}_{\mathrm{H}}$ and $\mathrm{V}_{\mathrm{L}}$ genes (corresponding to the FR1 in the $\mathrm{V}$ region), at the end of the $\mathrm{J}_{\mathrm{H}}$ or $\mathrm{J}_{\mathrm{L}}$ segments (FR4 in the rearranged $\mathrm{V}$ region) and at the proximal $\mathrm{C}_{\mathrm{L}}$ or $\mathrm{C}_{\mathrm{H} 1}$ constant regions $(81,94)$. Excellent databases are available on this subject: http://immuno. bme.nwu.edu (Elvin Kabat's Database) and http://www.mrc-cpe.cam.ac.uk/imt -doc/public/INTRO.html (the database of Human Antibody Genes).

Because different $\mathrm{V}$ and $\mathrm{J}$ germinal genes probably evolved from a single precursor and have strong sequence sim- ilarities-combined with the possibility of introducing degenerate positions in the primer-the number of synthetic oligonucleotide pairs required to prime at the $5^{\prime}$ - and 3 '-ends of any given $\mathrm{V}$ region can be reduced to a minimum.

Many example primer sets for the PCR cloning of $V$ regions can be found by searching the literature. The development of antibody combinatorial library technology boosted these efforts and has produced several reliable sets of PCR primers for both mouse and human $V$ regions $(37,83,107)$.

When designing antibody PCR primers, other characteristics to bear in mind include particular restriction enzyme sites and tags; expression strategies and specific vectors; and detection and purification strategies. In the case of mouse hybridomas, special care must be taken when designing the synthetic oligonucleotides to avoid (as much as possible) the amplification of an aberrant kappa RNA transcript that is present in many of these cells, inherited from the original MOPC-21 tumor from which most myeloma fusion partners are derived (21).

Conditions for successful antibody PCR have improved tremendously since the first reports. Now available are RNA extraction and cDNA kits, error-free thermostable DNA polymerases, designer reaction-buffer compositions and other PCR paraphernalia, from sophisticated thermocyclers to custom reaction tubes. Also, the large amount of accumulated information on new antibody sequences has decisively contributed to the explosive use of this simple, powerful technique.

\section{CHIMERIC AND HUMANIZED RECOMBINANT ANTIBODIES}

In the early 1980s, several groups developed the basis of what is now known as antibody genetic engineering $(53,116,122,151,166)$. With the pressing problem of an HAMA response after murine MAb treatment and the lack of desired effector functions, it is not surprising that the first recombinant therapeutic antibodies were prepared with a simple substitution of the murine constant domains by similar ones of human origin $(15,112,117)$. 
Table 1. Antibody Engineering: New Molecules and Technologies

$\begin{array}{ll}\begin{array}{l}\text { Chimeric } \\ \text { antibodies }\end{array} & \begin{array}{l}\text { Hybrid immunoglobulins in which the original murine variable regions are preserved and the constant re- } \\ \text { gions are switched for those of a human antibody to try to reduce HAMA and gain human effector functions. } \\ \text { Applications: Antibody therapy when effector and other Fc-associated functions and properties are needed. } \\ \text { Humanized }\end{array} \\ \text { antibodies } & \begin{array}{l}\text { Hybrid immunoglobulins in which the murine residues that conform to specific complementarity } \\ \text { determining regions and others of possible structural relevance are "transplanted" to a human antibody } \\ \text { framework. From here, the corresponding regions and residues have been eliminated to try to abrogate }\end{array} \\ & \text { HAMA and gain human effector functions. Applications: Antibody therapy when effector and other } \\ & \text { Fc-associated functions and properties are needed. } \\ \text { Antibody } & \text { Recombinant immunoglobulin fragments produced in bacteria or in yeast. These fragments include Fabs, } \\ \text { fragments } & \text { Fv and engineered Fv (scFv, dsFv), their variants minibodies, CRAbs, multifunctional } \\ & \text { and multi-specific diabodies, triabodies, tetrabodies) and fusion constructions (immunodrugs, } \\ & \text { immunotoxins, BRM). Applications: in vivo radioimmunodetection and in situ radiotherapy, drug, toxin } \\ & \text { and BRM-targeted delivery, detoxification of drugs and toxins, direct or indirect neutralization of viruses } \\ & \text { and microorganisms, effects on cell receptors and ligands, substitution of whole antibodies in } \\ & \text { immunoaffinity purification procedures, homogeneous diagnostic assays and catalysis. }\end{array}$

Intrabodies Antibodies and their fragments for which the genetic information is designed in a way that, after translation by the eukaryotic cell machinery, the resulting molecules will remain associated to different predefined cellular structures and compartments. Applications: Intracellular therapy.

Immunoglobulin Recombinant nucleic acid libraries of natural or synthetic origin that encode antibody binding sites libraries (Fab or scFv) for which the products (and corresponding genes) can be selected against an antigen of interest and subsequently modified to improve their affinity. Applications: Fast selection of new antibody binding sites from different species. Modification of pre-existing binding site affinity.

Transgenic Animals that have incorporated genetic information for the production of a foreign antibody or that have animals been subjected to a total or partial substitution of the endogenous immunoglobulin loci for foreign ones. Applications: Large-scale production of therapeutic antibodies, generation of human MAbs by conventional methods directly from mice.

Transgenic Plants modified genetically to constitutively produce functional antibodies or their fragments.

plants Applications: Large-scale production of therapeutic and industrial antibodies, modification of plant physiology, conference of plant resistance to infections, oral immunity.

To fabricate these chimeric antibodies, the $\mathrm{V}$ regions of the therapeutic murine antibody can be cloned by PCR and inserted into vectors carrying human gamma and kappa (or lambda) constant domains. These vectors can be prepared to include both chains for tandem expression, or they can be produced as separate plasmids for the heavy and light chains. Different host cell lines have been transfected with these chimeric genetic constructions using electroporation, liposome fusion or the calcium chloride method. Recipient cells include myelomas, Chinese hamster ovary ( $\mathrm{CHO}$ ) cells and insect cells. After seeding in a selective medium where only transfectomas will grow, the cultures are screened and cloned in a manner similar to conventional hybridomas. Among host cells, the $\mathrm{CHO}$ cells are preferred because of their more human-like glycosylation pattern and adaptability for high-density, large-scale cultivation in serum and protein-free media, an important aspect for production (136).

Compared to hybridomas, transfectomas secrete much lower amounts of antibodies and frequently lose antibody secretion. One approach to solving this problem has been to use the dihydrofolate reductase (DHFR) (66) selection and amplification system as part of the vectors to ensure multicopy integration and much higher antibody expression. While this selection works in Chinese hamster ovary cells, its use becomes more complex in myeloma cells because of endogenous DHFR activity. Celltech Ltd. (Slough, UK; http://www. celltech.com) has developed an alternative vector system for high expression of recombinant antibodies in cells of myeloid origin based on glutamine synthetase as a selectable marker and the almost absolute dependence of myelomas and hybridomas on exogenous glutamine for in vitro growth (9).

Chimeric antibodies show the same specificity and affinity of parental murine antibodies and are capable of efficiently mediating ADCC, antibodydependent macrophage cytotoxicity (ADMC) and complement fixation in the human context. In general, substitution of the murine constant regions by the human ones increases the biological half-life in vivo. Many chimeric versions of potential therapeutic murine antibodies have been evaluated in clinical trials (84). From these studies, it has become clear that, while in some cases chimerization caused a total disappearance of the HAMA response, many chimeric antibodies remained immuno- 
Table 2. Other Useful Antibody World Wide Web Sites

• http://www.ANTIBODIES-PROBES.com
• http://www.antibodyresource.com (Antibody Resource Page)
• http://www.biochem.ucl.ac.uk/ martin/abs/ (Antibody Structure and Sequence
Information)
• http://www.biodesign.com (BIODESIGN International: THE ANTIBODY
SOURCE)
• http://www.path.cam.ac.uk/ mrc7/ (Mike Clark's Home Page)
• http://www.path.cam.ac.uk/ mrc7/humanisation/antibodies.html (Mike Clark's:
Some Antibodies in Clinical Development)
• http://www.atcc.org/hdb/hdb.html (Monoclonal Connection-Hybridoma Data
Bank)
• http://aximt1.imt.uni-marburg.de/ rek/AEPstart.html (Antibody Engineering
Page by Roland Kontermann)

genic as a result of the presence of the murine $\mathrm{V}$ regions.

Another way of reducing the immunogenicity of murine $\mathrm{V}$ regions was reported by Mateo et al. (103). These authors mutated mouse $\mathrm{V}$ region T-cell epitopes to the homologous human sequences, leaving the complementarity- determining regions (CDRs) and the Vernier zone untouched. The antimouse response in primates was nullified by the chimeric antibodies produced by linking the remodeled mouse $\mathrm{V}$ regions to human constant domains.

The first fully humanized (reshaped) antibody (CAMPATH-1H) was produced by Reichmann et al. (134) using the anti-CD52 CAMPATH-1 rat antibody as target and the CDR-grafting technique originally proposed by Greg Winter and colleagues from the Medical Research Council (MRC) $(159,165)$. CDR-grafting involves the synthesis of a completely artificial $\mathrm{V}$ region using sequence information from the CDRs from the murine therapeutic antibody, combined with a compatible human framework (FR) sequence. The new, humanized $\mathrm{V}$ regions are linked to suitable human constant regions for expression of the complete immunoglobulin.

In their approach, Winter and coworkers proposed using the same human $\mathrm{V}$ region for the needed framework. If grafting the murine CDRs reduced or abolished the binding affinity, new constructs are prepared to incorporate additional mouse residues near the CDRs until original binding characteristics are restored (48). This work was soon followed by that of the Protein Design Labs group (Fremont, CA, USA; http://www. pdl.com), which was also based on CDR-grafting (134). However, the parental murine $\mathrm{V}$ region sequences are first matched to the most similar human ones using available databases. Computer modeling is then employed to identify those few murine residues that make key contacts with the CDRs. Rodent amino acids at these positions are then introduced into the human framework, together with the CDRs themselves.

While these engineered antibody molecules should not be considered fully human (see http://www.path.cam. ac.uk/ mrc7/reshaping/index.html for excellent discussion and review), humanized immunoglobulins undisputedly have shown far less HAMA response in clinical trials compared to their chimeric siblings $(135,167)$. They now account for a substantial percentage of immunoglobulin products in ongoing clinical trials.

Immunogenic epitopes can still be present in the reshaped $\mathrm{V}$ regions as a result of somatic mutation. Biovation (Aberdeen, UK; http://www.biovation. co.uk) offers the so-called "DeImmunisation" technology to remove immunogenic epitopes, even from CDRs, where appropriate (22).

\section{Other Antibody Constructions}

Antibodies can be produced as genetic fusion proteins with toxins, drugs, enzymes and other functional groups and modified in their constant domains to alter the original effector mechanisms and properties of the antibody molecule $(63,127,150)$.

Immunoadhesins (28) are fusion proteins that combine the hinge and Fc regions of an antibody with domains of a ligand-specific cell surface receptor. These molecules have advantages as laboratory experimental tools and as promising applications in medicine.

Antigenized antibodies (168) are made by grafting peptide epitopes derived from antigens that are different from immunoglobulins in the place of the CDR loops of an immunoglobulin. The conformationally restricted exposure of short foreign peptides using the $\mathrm{V}$ region framework and the characteristics of the constant antibody domains create promising combinations for immunoprophylaxis or immunotherapy. They can also be extended to the peptide hormone field and the rational design of new drugs.

Finally, Lunde et al. (99) have recently engineered anti-IgD antibodies with T-cell epitopes inserted into a constant region. This improves the 
efficiency of B cells to present antigens and stimulates specific $\mathrm{T}$ cells, an approach that may be useful in generating new vaccines.

\section{Antibody Fragments}

Antibody fragments have identical specificity and affinity to the parent antibody molecule. They can be produced with similar or increased avidity (multivalent fragments) or with half the avidity of the whole antibody molecule (monovalent fragments). Antibody fragments $\left(\mathrm{Fab}, \mathrm{F}\left(\mathrm{ab}^{\prime}\right)_{2}\right.$ and $\mathrm{Fv}$ ) have potential advantages over whole antibodies for many therapeutic uses because of their smaller size and potentially better tissue penetration and clearance (32). $\mathrm{Fab}$ (about $50 \mathrm{kDa}$ ) and $\mathrm{Fv}$ (about 25 $\mathrm{kDa}$ ) antibody fragments are rarely glycosylated, a fact that favors their expression in bacteria. Research on production of recombinant antibody fragments in bacteria and yeast was stimulated by their properties and potential applications and also because of the difficulties in controlled large-scale production of fragments by enzymatic means.

The first reports of antibody fragments produced in bacteria $(10,11,18$, $76,153)$ and yeast $(72)$ appeared more than 10 years ago. This work included the so-called single-chain Fv fragments $(\mathrm{scFv})$, artificial constructions where the individual heavy and light chain $\mathrm{V}$ regions are linked into a single protein using a short hydrophilic and flexible polypeptide linker (10-20 residues) $(77,129)$ made of amino acids that will not interfere with the packing of the hydrophobic interfaces of the $\mathrm{V}_{\mathrm{H}}-\mathrm{V}_{\mathrm{L}}$ heterodimer. ScFvs are stable at $37^{\circ} \mathrm{C}$, retain the specificity and affinity of the original Fv (about $27 \mathrm{kDa}$ ) and are easier to express compared with recombinant Fab, where two separate proteins must be expressed and then fold together. Also, scFv genes can be easily generated by PCR $(3,35)$. In addition to linker sequences, Fvs can be stabilized using other methods such as engineering of artificial disulfide bonds (86, 138) and glutaraldehyde treatment (55).

Antibody fragments, expressed in $E$. coli fused to signal peptide sequences, are exported to the bacterial periplasm, making the protein easily recoverable in active form. Apparently, the oxidizing environment of the periplasm mimics the endoplasmic reticulum of eukaryotic cells, allowing the formation of the intradomain disulfide bonds and the correct folding of the molecule. Alternatively, expression in the bacterial cytoplasm yields inactive antibody fragment chains produced either in soluble form or in aggregates (inclusion bodies) that need to be refolded in vitro after extraction $(16,19,29,41)$. Cytoplasmic formation of disulfide bonds and recovery of active antibody fragments have been reported in bacteria expressing thioredoxin reductase (133). A recent paper has extended these results to singlechain T-cell receptor fragments (111).

The choice of the final expression strategy (periplasm, cytoplasm, fusion proteins) will first depend on the particular amino acid sequences of the variable regions. These sequences can influence expression more than originally foreseen $(42,87)$ and vary from antibody to antibody. In the case of $\mathrm{scFv}$, it may be worthwhile to test both orientations $\left(\mathrm{V}_{\mathrm{H}}\right.$-linker- $\mathrm{V}_{\mathrm{L}}$ or $\mathrm{V}_{\mathrm{L}}$-linker- $\left.\mathrm{V}_{\mathrm{H}}\right)$ because some authors have document- ed effects of the $\mathrm{V}$ domain order on bacterial expression (4).

Many bacterial host strains can be used for $\mathrm{Fab}$ and $\mathrm{scF}$ p production. Because of the particular expression characteristics of each antibody fragment, it is recommended to assay several strains, both during the initial expression experiments and before scaling-up production. In terms of production, very high yields of antibody fragments in E. coli (up to 1-2 $\mathrm{g} / \mathrm{L}$ ) have been reported by some authors (23), but in most cases, production usually ranges between 20 and 200 $\mathrm{mg}$ pure active antibody fragment/liter of culture. Expression levels are dependent on the expression strategy (periplasm vs. cytoplasm), the type of fragment and the culture technique (124).

Several conventional chromatography methods have been used to purify bacterially produced antibody fragments, but immobilized metal ion affinity chromatography (IMAC) (131) has gained wide acceptance as a result of its simplicity, speed, low cost and performance. IMAC is based on the binding affinity of metal ions such as $\mathrm{Ni}^{2+}, \mathrm{Cu}^{2+}$ or $\mathrm{Zn}^{2+}$, chelated to a chromatography matrix, for multiple histidine residues genetically linked to the $\mathrm{N}$ - or C-terminus of an scFv or one of the Fv or Fab chains (154). IMAC also works in the presence of chaotropic agents such as urea or guanidium and can be used for $\mathrm{scFv}$ fragments expressed as cytoplasmic or periplasmic inclusion bodies that are first solubilized $(26,145)$.

Antibody fragments have also been expressed in fungi (120), mammalian cells (140) and insect cells (92). Production of antibody fragments from yeast cells (142) merits special mention. Antibody fragments have been expressed in Saccharomyces cerevisiae (90), Scizosaccharomyces pombe (35) and most recently in Pichia pastoris $(47,139)$. The last appears to be a system with excellent production characteristics and combines the general features of high capacity of secreted antibody fragment expression with fast growth and low levels of contaminant proteins in the medium (52).

The field of recombinant antibody fragments is probably where imagination has most expanded the range of potential products. Mono- and multivalent fragments of many different types, 
single or bispecific binding activity, genetic coupling to other proteins and functional groups and, more recently, single domain antibodies of different species origin are among the constructions tested to date $(73,74,141)$.

Antibody fragments are being developed for in vivo radioimmunodetection and in situ radiotherapy $(1,82,105)$; drug $(75)$, toxin $(91,104)$ and biological response modifier (BRM)-targeted delivery (108); detoxification of drugs and toxins (78); direct or indirect neutralization of viruses (38) and microorganisms; effects on cell receptors and ligands; substitution of whole antibodies in immunoaffinity purification procedures (126); homogeneous diagnostic assays (97) and catalysis $(121,149)$.

\section{Intrabodies}

Intrabodies are antibody fragments produced in mammalian cells with signals that traffic them to intracellular sites. If the problems of gene therapy (i.e., delivery of the intrabody genes) can be solved, this novel therapeutic form of antibody genes is expected to have great potential for therapeutic and prophylactic purposes $(57,101)$.

\section{Combinatorial Immunoglobulin Libraries in Phage}

Following the successful application of PCR to the isolation of individual V genes from RNA-cDNA and the expression of active periplasmic Fab and $\mathrm{scFv}$ fragments in microorganisms (particularly in E. coli), several groups created artificial combinatorial immunoglobulin libraries representing the pre-immune or immune antibody repertoires of a suitable animal. The basic rationale here was to extract total RNA from lymphocytes, construct cDNA and then to independently PCR-amplify the $\mathrm{H}$ and $\mathrm{L}$ chain $\mathrm{V}$ regions, using primer sets designed to hybridize at the ends of all known germinal $V$ and $J$ genes of a given species.

These individual $\mathrm{V}$ region DNA libraries were then combined in the form of $\mathrm{Fab}$ or $\mathrm{scFv}$ to recreate a repertoire of binding antibodies in vitro. Transformed bacteria each contained an individual clone representative of the preimmune antibody repertoire of the animal. After induction of expression, different antibodies could be identified using Western blot antigen-antibody recognition techniques (31).

RNA for combinatorial libraries can be obtained from different sources. Immunized animals will provide combinatorial libraries that are biased towards binding sites characteristic of the IgG high-affinity antibody, secondary response specific to the antigen. Combinatorial libraries derived from nonspecifically immunized (naive) animals or humans are expected to be more representative of the primary repertoire, although these will nevertheless have in their immune repertoires many antibodies with somatic mutations produced by natural immunization.

The size of the individually amplified $\mathrm{V}$ region DNA libraries and that of the product of their combination are important to determine the initial repertoire representation and then the possibility for practical use in the identification of a specific binding site. In the case of libraries from immunized animals, $10^{6}$ individual bacterial clones is probably an adequate size. With naive B-lymphocytes as source, the combinatorial libraries should have at least $10^{8}$ individual clones to recreate a representative sample of the original binding site repertoire. For such high numbers, efficiency is critical for the different steps that lead to the construction of the combinatorial library (RNA extraction, cDNA synthesis, individual PCR of $\mathrm{H}$ and $\mathrm{L} \mathrm{V}$ regions, ligation of $\mathrm{PCR}$ products and bacterial transformation).

However, an important drawback found early in the implementation of this work, especially when working with naive combinatorial libraries, involved the antigen screening method. For large libraries involving hundreds of millions of individual bacterial clones, the conventional filter lift procedures to screen for antibody fragment expression became impracticable.

While recent new flow cytometry technology has revitalized the interest in bacterial/yeast cell-surface display $(34,85)$, at the time the antibody library was in its original development, phage display technology solved this difficulty mentioned earlier.

Parmley and Smith (125) provided the experimental basis for this entire 
field by showing that peptides could be displayed on the surface proteins of filamentous bacteriophage in a way that could be recognized by antibodies. These experiments were followed by the work of McCafferty et al. (106) and Barbas et al. (6), which demonstrated that the reverse situation was also possible, that is, that functional antibody fragments displayed on phage could be specifically enriched by selection on immobilized antigen.

Filamentous bacteriophage such as $\mathrm{M} 13$, $\mathrm{fl}$ and fd are viruses that infect bacteria by interaction of the minor coat protein 3 in the phage with the $\mathrm{F}$ pili in the host bacteria. For example, M13 contains an ssDNA molecule that encodes 5 coat proteins, with protein 8 being the most abundant (up to 2700 copies compared with 5 copies for protein 3 ). After infection, the viral DNA replicates without cell lysis, and the different encoded proteins assemble in the inner bacterial membrane and the periplasm.

To display antibody fragments on phage, genetic fusions of the foreign protein (the $\mathrm{scFv}$ fragment or the $\mathrm{Fd}$ chain of a Fab) are made with either of the surface proteins, 3 or 8 . The multicopy nature of the gene 8 fusion proteins will create avidity effects when the virus particles are screened for antigen recognition, a potential disadvantage that has led to the preferred use of gene 3 fusions $(5,30)$. The antibody fragment genes can be cloned directly within the phage genome or fused to gene 3 or 8 segments present in phagemid plasmids. The latter strategy requires a helper virus to generate phage particles displaying the antibody-protein fusions. These hybrid particles will also display wild-type proteins encoded by the helper phage.

Phagemids have advantages over direct expression of the antibody genes in the viral genome for the construction of antibody libraries. Because of their small size (3-5 kb), their bacterial transformation efficiency is higher, a step that is limiting in the construction of very large libraries. Other strategies combine the high cloning efficiency of lambda phage with filamentous phage display, resulting in a good representation of the antibody repertoire (70). A second strategy used for this purpose is combinatorial infections, where the bacteria are transformed with the repertoire of one of the antibody chains and then infected with phage that carry the complementary chain (71). An improved variant of this system is that reported by Waterhouse et al. (161) in which combinatorial infection is combined with a site specific in vivo recombination system that facilitates the rescue of the gene of interest.

Large libraries permit an enhanced sampling of the sequence space or diversity of the antibody repertoire, making possible the detection of a wider range of antigen specificities $(98,128)$. Isolation of binding sites with higher affinities seems also to be a function of the size of the library $(37,58,119,146,157)$.

In addition to libraries obtained from either naive or immunized animals, it is possible to construct so-called synthetic libraries. These libraries start from mixtures of oligonucleotides that are assembled into complete V-region genes. One rendition of this idea, the huCAL library, has been pioneered by Morphosys GmbH in Germany (69). Anoth- er variant is semi-synthetic assembly, where previously cloned germinal $\mathrm{V}$ genes are used in combination with synthetic randomization of CDR3 (7). The first alternative is beneficial because it allows simultaneous randomization of the six CDRs.

Synthetic and semi-synthetic libraries can be constructed either with restricted $V$ gene usage (44) or by including all known $\mathrm{V}$ gene segments of the species (88). In the first case, it is assumed that only a fraction of all the germinal $V$ and $J$ genes are used in vivo, and thus, the size of the library can be limited with no major loss of representative medium affinity-binding sites for a variety of antigen structures.

Irrespective of the type and size of the library, screening for phage-displayed specific binding sites involves repeated cycles of selection with the antigen using a procedure generically known as biopanning. A sample of the combinatorial library phage stock is incubated with the antigen bound to a solid phase, the unbound phage are washed out and bound viral particles are then eluted. The putatively positive phage population is expanded in vitro by bacterial infection and submitted to three or four further rounds of selection. In this way, the phage population is progressively enriched (up to $10^{3}-$ $10^{4}$ times) in antibody fragments specific for the antigen in question.

Samples of phage obtained from each round of selection are individually characterized in terms of $\mathrm{V}$ region sequence and affinity for the antigen. The best binding sites are immediately available as antibody fragments or can be converted into full-length antibodies (2).

Cyclic panning can enrich for clones encoding high-affinity binders. This has proven to be of practical importance for the establishment of in vitro affinity maturation techniques. A limitation of some naive, semi-synthetic or synthetic phage libraries is the medium range value of the binding site affinity, as a result of the pre-immune status of the V-region genes used and a limited size of the library. To mimic in vivo somatic mutation, many in vitro techniques have been used to create mutations in the $\mathrm{V}$ regions of a phage displayed binding site (e.g., codon-based mutagenesis, error-prone PCR, nucleotide doping, parsimonious 


\section{Overview}

mutagenesis, E. coli mutator strains) and to take advantage of the diversity existing in individual $\mathrm{H}$ and $\mathrm{L}$ chain $\mathrm{V}$-region libraries (chain shuffling) $(8,102)$. These changes are then selected for improvement of affinity by panning under stringent conditions and introducing advanced methods for the determination of association and dissociation constants.

These methods can be applied to both antibody fragments derived from naive and synthetic libraries and also to MAbs cloned directly from hybridomas. Other methods to select binding phage are antigen-coated to magnetic beads, chromatography gels or the biotinylated antigen in solution followed by capture with streptavidin, etc. (36).

Recently, Dueñas and Borrebaeck (40) and Jung et al. (80) devised methods to link selection to infection, thus permitting phage display to mimic the in vivo situation when only B cells with specific receptors are activated. Al- though these methods have great promise, technical difficulties have limited their widespread application.

Combinatorial immunoglobulin libraries are attractive for many reasons. They overcome the limitations of chimerization and humanization of murine antibodies to rapidly isolate specific antibody-binding sites of fully human origin, without limitations imposed by the availability of donor lymphocytes or fusion partners. Phage and ribosomal display are fast and compatible with the possibility of high-throughput, automated screening. Different antigens can be used to screen the same library multiple times. When coupled to in vitro affinity maturation methods, combinatorial immunoglobulin library technology is a serious competitor for therapeutic human antibody production. This explains why several companies are forcefully claiming pieces of the technique's intellectual property pie, among them: Morphosys
GmbH (Munich, Germany; http://www. morphosys.com); Cambridge Antibody Technology (Cambridgeshire, UK; http: //www.catplc.co.uk) and Dyax (Cambridge, MA, USA; http://www.dyax.com).

\section{Cell-Free Ribosome Display of Antibodies}

Several groups have devised methods to link phenotype and genotype using free protein translation. Hanes and Plückthun (61) reported a system in which a correctly folded and complete protein, together with the encoding mRNA, remains attached to the prokaryotic ribosome, and can then be submitted to enrichment for ligand-binding properties. This procedure has been successfully developed using both prokaryotic and eukaryotic ribosomebased methods $(62,64,65,148)$. While these techniques are still quite exploratory, such revolutionary approach- 
es suggest that natively folded antibody fragment libraries can be made, screened and evolved in a completely cell-free system. The possibility for automated in vitro antibody identification and affinity maturation is obvious.

\section{Antibodies Produced In Transgenic Plants}

Functional antibodies produced in tobacco plants were first reported in 1989 (68). The basic protocol used to generate these plantibodies involved the independent cloning of heavy and light chain antibody genes in Agrobacterium tumefaciens vectors, the transformation of plant tissue in vitro with the recombinant bacterium, the reconstitution of whole plants expressing individual chains and their sexual cross. In a Mendelian fashion, a fully assembled and functional antibody was recovered from plant tissue in some double-transgenic plants.

In mammalian cells, the antibody $\mathrm{H}$ and $\mathrm{L}$ chains are produced as precursor proteins that are translocated into the endoplasmic reticulum under the guidance of signal sequences. Within the endoplasmic reticulum, the signal peptides are proteolytically cleaved, and several stress proteins act as chaperonins to bind the unassembled antibody chains and direct subsequent folding and tetramer formation. A similar process occurs in plant cells, and expression can be directed using signal sequences (even of foreign origin) into the aqueous environment of the apoplasm or to be accumulated in other specific plant tissues including tubers, fruit or seed (51).

Plant bioreactors are expected to yield over $10 \mathrm{~kg}$ therapeutic antibody/ acre in tobacco, maize, soybean and alfalfa. Compared to steel-tank bioreactors using mammalian cells or microorganisms, the plantibody costs are perhaps one-tenth for the GMP product.

The differences in glycosylation patterns of plant and mammalian cellproduced antibodies apparently have no effect on antigen binding or specificity, but there is some concern about potential immunogenicity in humans. $\mathrm{N}$-linked glycans of plants contain fucose-linked alpha $1 \rightarrow 3$ and the novel sugar, xylose. No evidence of toxicity or HAMA was observed in more than 40 patients receiving topical oral application of a secretory dimeric IgA specific to Streptococcus mutans for the control of caries (95).

The progressive improvement of vectors for plantibodies (67), purification strategies and the increase in transformable crop species could lead to the nearly limitless availability of inexpensive (even edible forms of) recombinant immunoglobulins for human and animal therapy and for industrial applications of antibodies (e.g., catalytic antibodies).

\section{Transgenic Animals}

Laboratory and domestic animal transgenesis has enormous potential to create new models of human disease, to study the physiological role of different gene products in "knock-out" individuals and to create transgenic animals as bioreactors for the production of therapeutic proteins. Transgenic mammals were first generated by in vitro microin- jection of a fertilized egg with the foreign DNA gene, its implantation into pseudopregnant foster mothers and the identification of the true transgenic progeny by PCR. In mice, the development of embryonic stem cell technology has simplified the initial step because these cultured cells can be easily transfected, manipulated in vitro and then implanted into a multicellular blastocyst, leading to transgenic animals. Homozygous progeny can be generated from the crosses of chimeric individuals.

There are at least three examples of the application of transgenic animal technology in the field of recombinant immunoglobulins. One is related to the use of transgenic animals as bioreactors with the production of antibodies in milk. The expression of many human proteins of therapeutic importance and found in the milk of transgenic animals has been well known for years, with average yields that amount to grams per liter in different domestic species (e.g., cattle, goat, sheep and pig). Mammary tissue-specific promoters can direct antibody production with correct assembly and function of the foreign antibodies in milk. Genzyme Transgenics (Framingham, MA, USA; http://www. genzyme.com/transgenics) has used this approach to make chimeric and humanized antibodies for clinical trials (130).

A second application of transgenic animal technology is to create animals that constitutively produce recombinant antibodies or antibody fragments capable of neutralizing common pathogens of the species.

Finally, animal transgenesis has been used to create mice that carry human variable and constant gene segments in germline configuration. These mice produce rearranged human antibodies in their B cells and produce human antibodies after conventional immunization procedures. Some encouraging results obtained by Abgenix (Freemont, CA, USA; http://www.abgenix.com) and Medarex (Princeton, NJ, USA; http:// www.medarex.com) have been recently published $(56,109,118,169)$.

Transgenic mouse strains that produce high-affinity human MAbs after immunization with different antigens (including human) using conventional hybridoma techniques were obtained when large size (mega-base) human 
genome fragments containing heavy or light chain genes were introduced into murine embryonic stem cells. These cells were then used for blastocyte injections. The resulting transgenic mice were then crossed with mice having disrupted endogenous heavy and light ( $\kappa)$ chain loci.

These transgenic mice produce human $\operatorname{IgM}$ and $\mathrm{IgG}$ antibodies at relatively high serum concentrations. The antibodies are composed of a high proportion of human $\kappa$ (not mouse $\kappa)$ and the usage/patterns of heavy and light chain $V, D$, and $J$ germinal genes are similar to what is found in human peripheral blood lymphocytes. Both the length of CDR3 and $\mathrm{N}$-addition are characteristically human. All the foreign antibody genes seem to be accessible to recombination/expression.

Abgenix (Xenomouse ${ }^{\mathrm{TM}}$ ) and Medarex (HuMAb-Mouse ${ }^{\mathrm{TM}}$ ) have developed transgenic mouse strains that produce antigen-specific human MAbs using conventional hybridoma technology. Hybrids developed in this way are stable and secrete large amounts of high-affinity (dissociation constant in the order of $10^{-9} \mathrm{M}$ ) antibodies. Some of these human antibodies are already in clinical trials.

Undoubtedly, these human immunoglobulin transgenic mice are the most important competitor to combinatorial antibody library technology for the generation of fully human therapeutic antibodies. Although they exploit the evolutionary mechanism of natural somatic mutation for high-affinity binders and the robustness of conventional hybridoma technology, there are several important points to be considered. As pointed out by Carl Borrebaeck in a recent letter to Nature Biotechnology (14), apart from investor enthusiasm and the commercial arguments that praise these mice as the fastest track to the clinic, the abnormal (mouse) glycosylation will still have to be considered when addressing the efficacy of these "human" antibodies in patients. Thus, $\mathrm{CHO}$ cells with a pattern of glycosylation more similar to that of human cells may be preferred for recombinant "humanized" antibody production. Last but not least, the commercial restrictions and high costs placed on this exciting technology will limit its availability to both academia and small institutions that may continue to use other "humanization" methods.

\section{THE FUTURE}

The diversity of antibody engineering technologies is astounding-synthetic combinatorial libraries, in vitro affinity maturation, cell-free libraries, large-scale production of antibodies in transgenic plants and animals, human MAbs from transgenic mice using conventional hybridoma techniques, chimeric and humanized antibodies, a myriad of antibody fragments, immunoadhesins, antigenized antibodies, intrabodies and so forth. These constructs and more will provide the basis of an incredible number of new therapeutic antibody-based products, besides acting as a transition to less costly and smaller synthetic molecules like bioactive peptides (164) and organic mimetics (146) that are derived from the antibody-binding site and CDR structure. In addition, the ideas gained from understanding antibodies will be used to construct so-called psi-bodies or pseudo-antibodies, which are proteins that scaffold randomized binding sites to generate novel binding and inhibitory activities.

Several areas of 21st-century science are expected to impact antibody engineering, particularly computational biology and the human genome. Knowledge of the basic features of the antigen-antibody interaction and modeling of the antibody-combining site will eventually develop to the point where it will be possible to computer model and design antibody-antigen pairs from the beginning. In five years, IBM expects to have developed Blue Gene, a computer that is 500 -fold faster than present day supercomputers to be used to predict protein folding (17). Such a powerful machine could rapidly solve antibody-protein binding problems.

The entire sequence of human chromosome 22 was recently reported (45). This year, the entire sequence of the human genome is expected to reach completion. Hundreds of thousands of antibodies will be required to identify and study the multitude of sequenced gene products. Some fraction of these anti- 
bodies will be therapeutic candidates, and others will be useful to identify drug leads and validate therapeutic concepts. Others will be important reagents for the rapidly growing field of proteomic research and will be used as integral components of so-called protein chips. New means to automate, generate and access antibody libraries will be important for this effort, and the Internet will readily make available to all an increasing amount of information about antibodies and related topics (Table 2).

Clearly, antibody engineering in all of its manifestations will be an important instrument in the toolbox of the molecular biologist of the 21st century. Let us end where we began by referring to the words of Emil von Behring, "I have no fear that the thought which forms the basis of serum therapy will ever disappear out of Medicine."

\section{ACKNOWLEDGMENTS}

The authors wish to thank Dr. Robert F. Balint for enlightened discussions, Ms. Jolande Murray for editorial help and Jasmine Wen Zhu for performance art.

\section{REFERENCES}

1.Adams, G.P. and R. Schier. 1999. Generating improved single-chain Fv molecules for tumor targeting. J. Immunol. Methods 231:249-260.

2.Ames, R.S., M.A. Tornetta, K. Deen, C.S. Jones, A.M. Swift and S. Ganguly. 1995 Conversion of murine Fabs isolated from a combinatorial phage display library to full length immunoglobulins. J. Immunol. Methods 184:177-186.

3.Ayala, M., M. Dueñas, A. Santos, J. Vázquez, A. Menéndez, A. Silva and J.V. Gavilondo. 1992. Bacterial single chain antibody fragments, specific for carcinoembryonic antigen. BioTechniques 13:790-799.

4.Ayala, M., M.E. Fernández-de-Cossío, L. Canaán-Haden, R.F. Balint, J.W. Larrick and J.V. Gavilondo. 1995. Variable region sequence modulates periplasmic export of a single chain $\mathrm{Fv}$ antibody fragment in $E$. coli. BioTechniques 18:832-842.

5.Barbas, III, C.F., A.S. Kang, R.A. Lerner and S.J. Benkovic. 1991. Assembly of combinatorial antibody libraries on phage surfaces: the gene III site. Proc. Natl. Acad. Sci. USA 88:7978-7982.

6.Barbas, C.F., III, and R.A. Lerner. 1991. Combinatorial immunoglobulin libraries on the surface of phage (Phabs): rapid selection of antigen specific Fabs. Methods: A Com- panion to Methods Enzymol. 2:119-124.

7.Barbas, III, C.F., J.D. Bain, D.M. Hoekstra and R.A. Lerner. 1992. Semisynthetic combinatorial antibody libraries: a chemical solution to the diversity problem. Proc. Natl. Acad. Sci. USA 89:4457-4461.

8.Barbas, III, C.F., D. Hu, N. Dunlop, L. Sawyer, D. Cababa, R.M. Hendry, P.L. Nara and D.R. Burton. 1994. In vitro evolution of a neutralizing human antibody to human immunodeficiency virus type 1 to enhance affinity and broaden strain cross reactivity. Proc. Natl. Acad. Sci. USA 91: 3809-3813

9.Bebbington, C.R., G. Renner, S. Thomson, D. King, D. Abrams and G.T. Yarranton. 1992. High-level expression of a recombinant antibody from myeloma cells using a glutamine synthetase gene as an amplifiable selectable marker. Bio/Technology 10:169-175.

10.Better, M., C.P. Chang, R.R. Robinson and A.H. Horwitz. 1988. Escherichia coli secretion of an active chimeric antibody fragment. Science 240:1041-1043.

11.Bird, R.E., K.D. Hardman, J.W. Jacobson, S. Johnson, B.M. Kaufman, S.-M. Lee, T. Lee, S.H. Pope, G.S. Riordan and M. Whitlow. 1988. Single chain antigen binding proteins. Science 242:423-426.

12.Borrebaeck, C.A.K. 1989. Strategy for the production of human monoclonal antibodies using in vitro activated B cells. J. Immunol. Methods 123:157-165.

13.Borrebaeck, C.A.K. (Ed.) 1995. Antibody Engineering. Oxford University Press. New York.

14.Borrebaeck C.A.K. 1999. Human monoclonal antibodies: the emperor's new clothes? Nat. Biotechnol. 17:821.

15.Boulianne, G.L., N. Hozumi and M.J. Shulman. 1984. Production of functional chimeric mouse/human antibodies. Nature 312:643646.

16.Buchner, J. and R. Rudolph. 1991. Renaturation, purification, and characterization of recombinant Fab-fragments produced in Escherichia coli. Bio/Technology 9:157-161.

17.Butler, D. 1999. IBM promises scientists 500 -fold leap in supercomputing power. Nature 402:705-706.

18.Cabilly, S., A.D. Riggs, H. Pande, J.E. Shively, W.E. Holmes, M. Rey, L.J. Perry, R. Wetzel and H.L. Heyneker. 1984. Generation of antibody activity from immunoglobulin polypeptide chains produced in EScherichia coli. Proc. Natl. Acad. Sci. USA 81:3273-3277.

19.Canaán-Haden, L., M. Ayala, M.E. Fernández-de-Cossio, I. Pedroso, L. Rodés and J.V. Gavilondo. 1995. Purification and application of a single chain Fv antibody fragment specific to hepatitis B virus surface antigen. BioTechniques 19:606-614.

20.Caroll, W.L., K. Thielemans, J. Dilley and R. Levy. 1986. Mouse x human heterohybridomas as fusion partners with human B cell tumors. J. Immunol. Methods 89:61-72.

21.Caroll, W.L., E. Mendel and S. Levy. 1988. Hybridoma fusion cell lines contain an aberrant kappa transcript. Mol. Immunol. 25:991995.

22.Carr, F.J., G. Carter and A. Hamilton.
2000 (issued). Method for the production of non-immunogenic proteins. EP 983303A1.

23.Carter, P., R.F. Kelley, M.L. Rodrigues, B. Snedecor, M. Covarrubias, M.D. Velligan, W.-L.T. Wong, A.M. Rowland et al. 1992. High level Escherichia coli expression and production of a bivalent humanized antibody fragment. Bio/Technology 10:163-167.

24.Casadevall, A. and M.D. Scharff. 1995. Return to the past: the case for antibody based therapies in infectious diseases. Clin. Infect. Dis. 21:150-161.

25.Casadevall, A. 1996. Antibody-based therapies for emerging infectious diseases. Emerg. Infect. Dis. 2:200-208.

26.Casalvilla, R., M. Dueñas, M. Ayala, S. Cruz, L. Cruz, W.A. Buurman and J.V. Gavilondo. 1999. A bacterial single-chain Fv antibody fragment that inhibits binding of its parental anti-E selectin monoclonal antibody to activated human endothelial cells. J. Biotechnol. 72:1-12.

27.Cavaillon, J.-M. 1994. Controversies surrounding current therapies for sepsis syndrome. Bull. Inst. Pasteur 93:21-41.

28.Chamov, S.M. and A. Ashkenazi. 1996. Immunoadhesins: principles and applications. TIBTECH 14:52-59.

29.Chaudhary, V.K., J.K. Batra, M.G. Gallo, M.C. Willingham, D.J. Fitzgerald and I. Pastan. 1990. A rapid method of cloning functional variable region antibody genes in Escherichia coli as single-chain immunotoxins. Proc. Natl. Acad. Sci. USA 87:10661070.

30.Chiswell, D.J. and J. McCafferty. 1992. Phage antibodies: will new coliclonal antibodies replace monoclonal antibodies? TIBTECH 10:80-84.

31.Clackson, T. and J.A. Wells. 1994. In vitro selection from protein and peptide libraries. TIBTECH 12:173-184.

32.Colcher, D., G. Pvlinkova, G. Beresford, B.J.M. Booth, A. Choudhury and S.K. Batra. 1998. Pharmacokinetics and biodistribution of genetically-engineered antibodies. Q. J. Nuclear Med. 42:225-241.

33.Dall'Acqua, W. and P. Carter. 1998. Antibody Engineering. Curr. Opin. Oncol. 10:548-551.

34.Daugherty, P.S., G. Chen, M.J. Olsen, B.L. Iverson and G. Georgiou. 1998. Antobody affinity maturation using bacterial surface display. Protein Eng. 11:825-832.

35.Davis, G.T., W.D. Bedzyk, E.W. Voss and T.W. Jacobs. 1991. Single chain antibody (SCA) encoding genes: one-step construction and expression in eukaryotic cells. Bio/Technology 9:165-169.

36.de Haard, H., P. Henderikx and H.R. Hoogenboom. 1998. Creating and engineering human antibodies for immunotherapy. Adv. Drug Delivery Rev. 31:5-31.

37.de Haard, H.J., N. van Neer, A. Reurs, S.E. Hufton, R.C. Roovers, P. Henderikx, A.P. de Bruine, J.-W. Arends and H.R. Hoogenboom. 1999. A large non-immunized human Fab fragment phage library that permits isolation and kinetic analysis of high affinity antibodies. J. Biol. Chem. 274:18118-18230.

38.Delagrave, S., J. Catalan, C. Sweet, G. Drabik, A. Henry, A. Rees, T.P. Monath and F. 
Guirakhoo. 1999. Effects of humanization by variable domain resurfacing on the antiviral activity of a single-chain antibody against respiratory syncytial virus. Protein Eng. 12:357-362.

39.Dickman, S. 1998. Antibodies stage a comeback in cancer treatment. Science 280:11961197.

40.Dueñas, M. and C.A.K. Borrebaeck. 1994 Clonal selection and amplification of phage displayed antibodies by linking antigen recognition and phage replication. Bio/Technology 12:999-1002.

41.Dueñas, M., J. Vázquez, M. Ayala, E. Soderlind, M. Ohlin, L. Pérez, C.A.K. Borrebaeck and J.V. Gavilondo. 1994. Intraand extracellular expression of a scFv antibody fragment in $E$. coli: effect of bacterial strains and pathway engineering using GroES/L chaperonins. BioTechniques 16:476483.

42.Dueñas, M., M. Ayala, J. Vázquez, M. Ohlin, E. Soderlind, C.A.K. Borrebaeck and J. Gavilondo. 1995. A point mutation in a murine immunoglobulin V-region strongly influences the antibody yield in Escherichia coli. Gene 158:61-66.

43.Dueñas, M., L.-T. Chin, A.C. Malmborg, R. Casalvilla, M. Ohlin and C.A.K. Borrebaeck. 1996. In vitro immunization of naïve B cells yields high affinity human IgG antibodies as illustrated by phage display. Immunology 89:1-7.

44.Dueñas, M. and J.C. Almagro. 1997. Construction and selection of scFv antibody fragments from restricted human libraries. Short Report. Advances in Modern Biotechnology Vol IV. Proceedings of the International Congress Biotecnología Habana'97. Elfos Scientiae. La Habana, Cuba. December 1-6. pp. R8.

45.Dunham, I., N. Shimizu, B.A. Roe, S. Chissoe, A.R. Hunt, J.E. Collins, R. Bruskiewich, D.M. Beare et al. 1999. The DNA sequence of human chromosome 22. Nature 402:489-495.

46.Ekberg, H., L. Backman, G. Tufveson and G. Tyden. 1999. Zenapax (daclizumab) reduces the incidence of acute rejection episodes and improves patient survival following renal transplantation. Transplant. Proc. 31: 267-268.

47.Eldin, P., M.E. Pauza, Y. Hieda, G. Lin, M.P. Murtaugh, P.R. Pentel and C.A. Pennell. 1997. High level secretion of two antibody single chain Fv fragments by Pichia pastoris. J. Immunol. Methods 201:67-75

48.Emery, S.C. and W.J. Harris. 1995. Strategies for humanizing antibodies. p. 159-183. In C.A.K. Borrebaeck (Ed.), Antibody Engineering. Oxford University Press, New York.

49.Farah, R.A., B. Clinchy, L. Herrera and E.S. Vitetta. 1998. The development of monoclonal antibodies for the therapy of cancer. Gene Expr. 8:321-345.

50.Ferguson, M., P.D. Minor, A.J. Garret, M. Page, R. Thorpe and T. Barrowcliffe. 1996. Testing plasma pools for markers of viral contamination: the UK experience. Vox Sang. 71:21-26.

51.Fiedler, U. and U. Conrad. 1995. High-level production and long-term storage of engi- neered antibodies in transgenic tobacco seeds. Bio/Technology 13:1090-1093.

52.Freyre, F.M., J.E. Vázquez, M. Ayala, L. Canaán-Haden, H. Bell, I. Rodríguez, A. González, A. Cintado and J.V. Gavilondo. High level expression of an anti-CEA single chain Fv antibody fragment in the methylotrophic yeast Pichia pastoris. J. Biotechnol. (In Press).

53.Gillies, S.D., S.L. Morrison, V.T. Oi and S. Tonegawa. 1983. A tissue-specific transcription enhancer element is located in the major intron of rearranged immunoglobulin heavy chain gene. Cell 33:717-729.

54.Glaser, V. 1996. Can ReoPro repolish tarnished monoclonal therapeutics? Nat. Biotechnol. 14:1216-1217.

55.Glockshuber, R., M. Malia, I. Pfitzinger and A. Plückthun. 1990. A comparison of strategies to stabilize immunoglobulin Fv fragments. Biochemistry 29:1362-1367.

56.Green, L.L. 1999. Antibody engineering via genetic engineering of the mouse: XenoMouse strains are a vehicle for the facile generation of therapeutic human monoclonal antibodies. J. Immunol. Methods 231:11-23.

57.Greenman, J., E. Jones, M.D. Wright and A.N. Barclay. 1996. The use of intracellular single-chain antibody fragments to inhibit specifically the expression of cell surface molecules. J. Immunol. Methods 194:169180

58.Griffiths, A.D., S.C. Williams, O. Hartley, I.M. Tomlinson, P. Waterhouse, W.L. Crosby, R.E. Kontermann, P.T. Jones et al. 1994. Isolation of high affinity human antibodies directly from large synthetic repertoires. EMBO J. 13:3245-3260.

59.Grillo-Lopez, A.J., C.A. White, C. Varns, D. Shen, A. Wei, A. McClure and B.K. Dallaire. 1999. Overview of the clinical development of rituximab: first monoclonal antibody approved for the treatment of lymphoma. Semin. Oncol. 26:66-73.

60.Grunow, R., S. Jahn, T. Porstmann, S.S. Kiessig, H. Steinkellner, F. Steindl, D. Mattanovich, L. Gurtler et al. 1988. The high efficiency human B cell immortalizing heteromyeloma CB-F7. Production of human monoclonal antibodies to human immunodeficiency virus. J. Immunol. Methods 106:257265.

61.Hanes, J. and A. Plückthun. 1997. In vitro selection and evolution of functional proteins by using ribosome display. Proc. Natl. Acad. Sci. USA 94:4937-4942.

62.Hanes, J., L. Jermutus, C. Schaffitzel and A. Plückthun. 1999. Comparison of Escherichia coli and rabbit reticulocyte ribosome display systems. FEBS Lett. 450:105110.

63.Harvill, E.T., J.M. Fleming and S.L. Morrison. 1996. In vivo properties of an IgG3-IL2 fusion protein. A general strategy for immune potentiation. J. Immunol. 157: 3165-3170.

64.He, M. and M.J. Taussig. 1997. Antibody-ribosome-mRNA (ARM) complexes as efficient selection particles for in vitro display and evolution of antibody combining sites. Nucleic Acids Res. 25:5132-5134.

65.He, M., M. Menges, M.A. Groves, E.
Corps, H. Liu, M. Bruggemann and M.J. Taussig. 1999. Selection of a human antiprogesterone antibody fragment from a transgenic mouse library by ARM ribosome display. J. Immunol. Methods 231:105-117.

66.Hendricks, M.B., C.A. Luchette and M.J. Banker. 1989. Enhanced expression of an immunoglobulin-based vector in myeloma cells mediated by co-amplification with a mutant dihydrofolate reductase gene. Bio/Technology 7:1271-1274.

67.Hendy, S., Z.C. Chen, H. Barker, S. Santa Cruz, S. Chapman, L. Torrance, W. Cockburn and G.C. Whitelam. 1999. Rapid production of single-chain Fv fragments in plants using a potato virus $\mathrm{X}$ episomal vector. J. Immunol. Methods 231:137-146.

68.Hiatt, A., R. Cafferkey and K. Bowdish. 1989. Production of antibodies in transgenic plants. Nature 342:76-87.

69.Hoess, A, J. Wolle, L. Ge, P. Pack, P. Kufer and A. Knappik. 1997. Generation of human antibodies that selectively recognize diseased cells overexpressing surface bound antigens. Proc. Annu. Meet. Am. Assoc. Cancer Res. 38:A198.

70.Hogrefe, H., R. Mullinax, A. Lovejoy, B. Hay and J. Sorge. 1993. A bacteriophage vector for the cloning and expression of immunoglobulin Fab fragments on the surface of filamentous phage. Gene 128:119-126.

71.Hoogenboom, H., A. Griffiths, K. Johnson, D. Chiswell, P. Hudson and G. Winter. 1991. Multisubunit proteins on the surface of filamentous phage: methodologies for displaying antibody (Fab) heavy and light chains. Nucleic Acids Res. 19:4133-4137.

72.Horwitz, A.H., C.P. Chang, M. Better, K.E. Hellstrom and R.R. Robinson. 1988. Secretion of functional antibody and Fab fragments from yeast cells. Proc. Natl. Acad. Sci. USA 85:8678-8682.

73.Hudson, P.J. 1999. Recombinant antibody constructs in cancer therapy. Curr. Opin. Immunol. 11:548-557.

74.Hudson, P.J. and A.A. Kortt. 1999. High avidity $\mathrm{scFv}$ multimers: diabodies and triabodies. J. Immunol. Methods 231:177-189.

75.Huennekens, F.M. 1994. Tumor targeting: activation of prodrugs by enzyme-monoclonal antibody conjugates. TIBTECH 12:234238.

76.Huston, J.S., D. Levinson, M. MudgettHunter, M. Tai, J. Novotny, M.N. Margolies, R.J. Ridge, R.E, Bruccoleri et al. 1988. Protein engineering of antibody binding sites: recovery of specific activity in an anti-digoxin single chain $\mathrm{Fv}$ analoque produced in Escherichia coli. Proc. Natl. Acad. Sci. USA 85:5879-5883.

77.Huston, J.S., M. Mudgett-Hunter, M.S. Tai, J. McCartney, F. Warren, E. Haber and H. Oppermann. 1991. Protein engineering of single-chain Fv analogs and fusion proteins. Meth. Enzymol. 203:46-88.

78.Huston, J. 1993. Medical applications of single-chain antibodies. Int. Rev. Immunol. 10:195-217.

79.Jardieu, P.M. and R.B. Fick, Jr. 1999. IgE inhibition as a therapy for allergic disease. Int. Arch. Allergy Immunol. 118:112-115.

80.Jung, S., K.M. Arndt, K.M. Muller and A. 
Plückthun. 1999. Selectively infective phage (SIP) technology: scope and limitations. J. Immunol. Methods 231:93-104.

81.Kabat, E., T.E. Wu, H. Perry, K.S. Gottesman and C. Foeller. 1991. Sequences of Proteins of Immunological Interest. US Department of Health and Human Services. Public Health Service. NIH Publication No. 913242.

82.Kairemo, K.J.A. 1996. Radioimmunotherapy of solid cancers. Acta Oncol. 35:343-355.

83.Kettleborough, C.A., J. Saldanha, K.H. Ansell and M.M. Bendig. 1993. Optimization of primers for cloning libraries of mouse immunoglobulin genes using the polymerase chain reaction. Eur. J. Immunol. 23:206-211.

84.Khazaeli, M.B., R.M. Conry and A.F. LoBuglio. 1994. Human immune response to monoclonal antibodies. J. Immunother. 15:42-52.

85.Kieke, M.C., E.V. Shusta, E.T. Boder, L. Teyton, K.D. Wittrup and D.M. Kranz. 1999. Selection of functional T cell receptor mutants from a yeast surface-display library. Proc. Natl. Acad. Sci. USA 96:5651-5656.

86.Kipriyanov, S.M., S. Dubel, F. Breitling, R.E. Kontermann, S. Heyman and M. Little. 1995. Bacterial expression and refolding of single chain Fv fragments with C-terminal cysteines. Cell Biophys. 26:187-204.

87.Knappik, A. and A. Plückthun. 1995. Engineered turns of an antibody improve its in vivo folding. Protein Eng. 8:81-89.

88.Knappik, A. 1997. Recombinant human antibodies which can be routinely optimized. "Antibody Therapeutic Antibodies '97”, Larrick, J.W., Burton, D. (org.), San Francisco, California, September 21-24.

89.Köhler, G. and C. Milstein. 1975. Continuous cultures of fused cells secreting antibody of predefined specificity. Nature 256:52-53.

90.Kotula, L. and P.J. Curtis. 1991. Evaluation of foreign gene codon optimization in yeast: expression of a mouse Ig kappa chain. Bio/Technology 9:1386-1389.

91.Kreitman, R.J., W.H. Wilson, D. Robbins, I. Margulies, M. Stetler-Stevenson, T.A. Waldmann and I. Pastan. 1999. Responses in refractory hairy cell leukemia to a recombinant immunotoxin. Blood 94:3340-3348.

92.Kretzschmar, T., L. Aoustin, O. Zingel, M. Marangi, B. Vonach, H. Towbin and $M$. Geiser. 1996. High-level expression in insect cells and purification of secreted monomeric single-chain Fv antibodies. J. Immunol. Methody 195:93-101.

93.Larrick, J.W., Y.L. Chiang, R. ShengDong, G. Senck and P. Casali. 1988. Generation of specific human monoclonal antibodies by in vitro expansion of human B-cells: a novel recombinant DNA approach. p. 231246. In C.A.K. Borrebaeck (Ed.), In Vitro Immunization and Hybridoma Technology. Elsevier Science, Amsterdam.

94.Larrick, J.W., L. Danielsson, C.A. Brenner, M. Abrahamson, K.E. Fry and C.A.K. Borrebaeck. 1989. Rapid cloning of rearranged immunoglobulin genes from human hybridoma cells using mixed primers and the polymerase chain reaction. Biochem. Biophys. Res. Commun. 160:1250-1256.

95.Larrick, J.W., L. Yu, J. Chen, S. Jaiswal and K. Wycoff. 1998. Production of antibodies in transgenic plants. Res. Immunol. 149:603-608

96.Levy, R. and R. Miller. 1983. Biological and clinical implications of hybridomas: tumor therapy with monoclonal antibodies. Annu. Rev. Med. 14:1352-1359.

97.Lilley, G., O. Dolezal, C.J. Hillyard, C. Bernard and P.J. Hudson. 1994. Recombinant single-chain antibody peptide conjugates expressed in Escherichia coli for the rapid diagnosis of HIV. J. Immunol. Methods 171:211-226.

98.Little, M., M. Welschof, M. Braunagel, I. Hermes, C. Christ, A. Keller, P. Rohrbach, T. Kurschner et al. 1999. Generation of a large complex antibody library from multiple donors. J. Immunol. Methods 231:3-9.

99.Lunde, E., L.A. Munthe, A. Vabo, I. Sandlie and B. Bogen. 1999. Antibodies engineered with $\operatorname{IgD}$ specificity efficiently deliver integrated T-cell epitopes for antigen presentation by B cells. Nat. Biotechnol. 17:670675.

100.Maini, R., E.W. St Clair, F. Breedveld, D. Furst, J. Kalden, M. Weisman, J. Smolen, P. Emery et al. 1999. Infliximab (chimeric anti-tumour necrosis factor alpha monoclonal antibody) versus placebo in rheumatoid arthritis patients receiving concomitant methotrexate: a randomised phase III trial. ATTRACT Study Group. Lancet 354:1932-1939.

101.Marasco, W.A., J. LaVecchio and A. Winkler. 1999. Human anti-HIV-1 tat sFv intrabodies for gene therapy of advanced HIV-1infection and AIDS. J. Immunol. Methods 231:223-238

102.Marks, J.D., A.D. Griffiths, M. Malqvist, T.P. Clackson, J.M. Bye and G. Winter. 1992. By-passing immunization: building high affinity human antibodies by chain shuffling. Bio/Technology 10:779-783.

103.Mateo, C., E. Moreno, K. Amour, J. Lombardero, W. Harris and R. Pérez. 1997. Humanization of a mouse monoclonal antibody that blocks the epidermal growth factor receptor: recovery of antagonistic activity. Immunotecnol. 3:71-81.

104.Maurer Reiter, Y. and I. Pastan. 1998. Recombinant $\mathrm{Fv}$ immunotoxins and Fv fragments as novel agents for cancer therapy and diagnosis. Trends Biotechnol. 18:513-520.

105.Mayer, A., K.A. Chester, A.A. Flynn and R.H. Begent. 1999. Taking engineered antiCEA antibodies to the clinic. J. Immunol. Methods 231:261-273.

106.McCafferty, J., A.D. Griffiths, G. Winter and D. Chiswell. 1990. Phage antibodies: filamentous phage displaying antibody variable domains. Nature 348:552-554.

107.McCafferty, J. and K.S. Johnson. 1996. Construction and screening of antibody display libraries. Phage Display of Peptides and Proteins. Academic Press, San Diego.

108.Melani, C., M. Figini, D. Nicosia, E. Luison, V. Ramakrishna, G. Casorati, G. Parmiani, Z. Eshhar, S. Canevari and M.P. Colombo. 1998. Targeting of interleukin 2 to human ovarian carcinoma by fusion with a singlechain Fv of antifolate receptor antibody. Cancer Res. 58:4146-4154.

109.Mendez, M.J., L.L. Gree, J.R.F. Corvalan,
X.-C. Jia, C.E. Maynard-Currie, X.-D. Yang, M.L. Gallo, D.M. Louie et al. 1997. Functional transplant of megabase human immunoglobulin loci recapitulates human antibody response in mice. Nat. Genet. 15:146156.

110.Milgrom, H., R.B. Fick, Jr, J.Q. Su, J.D. Reimann, R.K. Bush, M.L. Watrous and W.J. Metzger. 1999. Treatment of allergic asthma with monoclonal anti-IgE antibody. rhuMAb-E25 Study Group. N. Engl. J. Med. 341:1966-1973.

111.Molloy, P.E., W.J. Harris, G. Strachan, C. Watts and C.P. Cunningham. 1998. Production of soluble single-chain T-cell receptor fragments in Escherichia coli trxB mutants. Mol. Immunol. 35:273-281.

112.Morrison, S.L., M.J. Johnson, L.A. Herzenberg and V.T. Oi. 1984. Chimaeric human antibody molecules: mouse antigen binding domains. Proc. Natl. Acad. Sci. USA 82: 6851-6855.

113.Morrison, S.L. 1985. Transfectomas provide novel chimeric antibodies. Science 229:12021207.

114.Mullis, K.B., F. Faloona, S. Scharf, R. Saiki, G. Horn and H. Erlich. 1986. Specific enzymatic amplification of DNA in vitro: the polymerase chain reaction. Cold Spring Harb. Symp. Quant. Biol. 1:263-273.

115.Mulloy, L.L., F. Wright, M.L. Hall and M. Moore. 1999. Simulect (basiliximab) reduces acute cellular rejection in renal allografts from cadaveric and living donors. Transplant. Proc. 31:1210-1213

116.Neuberger, M.S. 1983. Expression and regulation of immunoglobulin heavy chain gene transfected into lymphoid cells. EMBO J. 2:1373-1378.

117.Neuberger, M.S., G.T. Williams and R.O. Fox. 1984. Recombinant antibodies possessing novel effector functions. Nature 312:604608 .

118.Neuberger, M. and M. Gruggermann. 1997. Monoclonal antibodies. Mice perform a human repertoire. Nature 386:25-26.

119.Nissim, A., H.R. Hoogenboom, I.M. Tomlinson, G. Flynn, C. Midgely, D. Lane and G. Winter. 1994. Antibody fragments from single pot phage display library as immunochemical reagents. EMBO J. 13:692-698.

120.Nyyssonen, E., M. Penttila, A. Harkki, A. Saloheimo, J.K.C. Knowles and S. Keranen. 1993. Efficient production of antibody fragments by the filamentous fungus Trichoderma reseei. Bio/Technology 11:591-595.

121.Ohage, E.C., P. Wirtz, J. Barnikow and B. Steipe. 1999. Intrabody construction and expression. II. A synthetic catalytic Fv fragment. J. Mol. Biol. 291:1129-1134.

122.Oi, V.T., S.L. Morrison, L.A. Herzenberg and P. Berg. 1983. Immunoglobulin gene expression in transformed lymphoid cells. Proc. Natl. Acad. Sci. USA 80:825-829.

123.Orlandi, R., D.H. Gussow, P.T. Jones and G. Winter. 1989. Cloning immunoglobulin variable domains for expression by the polymerase chain reaction. Proc. Natl. Acad. Sci. USA 86:3833-3837.

124.Pack, P., M. Kujau, M., Schroeckh, U. Knupfer, R. Wenderoth, D. Riesenberg and A. Plückthun. 1993. Improved bivalent mini- 
antibodies, with identical avidity as whole antibodies, produced by high cell density fermentation of Escherichia coli. Bio/Technology 11:1271-1277.

125.Parmley, S.F. and G.P. Smith. 1988. Antibody-selectable filamentous fd phage vectors: affinity purification of target genes. Gene 73:305-318

126.Pedroso, I., A. Agraz, J. Brito, R. Páez, J.L. Segredo, J. García, M. Pérez, V. Lugo et al. 1997. Immunoaffinity purification of a particulate recombinant $\mathrm{HBsAg}$ using single-chain Fv antibody fragments. Minerva Biotecnologica 9:68-75.

127.Penichet, M.L., Y.S. Kang, W.M. Pardridge, S.L. Morrison and S.U. Shin. 1999. An antibody-avidin fusion protein specific for the transferrin receptor serves as a delivery vehicle for effective brain targeting: initial applications in anti-HIV antisense drug delivery to the brain. J. Immunol. 163:4421-4426.

128.Persson, M.A.A., R.H. Caothien and D.R. Burton. 1991. Generation of diverse highaffinity human monoclonal antibodies by repertoire cloning. Proc. Natl. Acad. Sci. USA 88:2432-2436.

129.Plückthun, A. 1991. Strategies for the expression of antibody fragments in Escherichia coli. Methods: A Companion to Methods Enzymol. 2:88-96.

130.Pollock, D.P., J.P. Kutzko, E. Birck-Wilson, J.L. Williams, Y. Echelard and H.M. Meade. 1999. Transgenic milk as a method for the production of recombinant antibodies. J. Immunol. Methods 231:147-157.

131.Porath, J. 1992. Immobilized metal ion affinity chromatography. Protein Expr. Purif. 3:263-281.

132.Present, D.H. 1999. Review article: the efficacy of infliximab in Crohn's disease-healing of fistulae. Aliment Pharmacol. Ther. 13:23-28.

133.Proba, K., L. Ge and A. Plückthun. 1995. Functional antibody single chain fragments from the cytoplasm of $E$. coli: influence of thioredoxin reductase (TrxB). Gene 159:203207.

134.Queen, C. and H.E. Selick. 1996 (issued). Humanized immunoglobulins. US5530101.

135.Rebello, P.R., G. Hale, P.J. Friend, S.P. Cobbold and H. Waldmann. 1999. Antiglobulin responses to rat and humanized CAMPATH-1 monoclonal antibody used to treat transplant rejection. Transplantation 68:1417-1420.

136.Reff, M.E. 1993. High-level production of recombinant immunoglobulins in mammalian cells. Curr. Opin. Biotechnol. 4:573-576.

137.Reichmann, L., M. Clark, H. Waldmann and G. Winter. 1988. Reshaping human antibodies for therapy. Nature 332:323-327.

138. Reiter, Y., U. Brinkmann, B. Lee and I. Pastan. 1996. Engineering antibody Fv fragments for cancer detection and therapy: disulfide-stabilized Fv fragments. Nat. Biotechnol. 14:1239-1245.

139.Ridder, R., R. Schmitz, F. Legay and H. Gram. 1995. Generation of rabbit monoclonal antibody fragments from a combinatorial phage display library and their production in the yeast Pichia pastoris. Bio/Technology $13: 255-260$.
140.Riechmann, L., J. Foote and G. Winter. 1988. Expression of an antibody $\mathrm{Fv}$ fragment in myeloma cells. J. Mol. Biol. 203:825-828.

141.Riechmann L. and S. Muyldermans. 1999. Single domain antibodies: comparison of camel $\mathrm{HH}$ and camelised human $\mathrm{HH}$ domains. J. Immunol. Methods 231:25-38.

142.Romanos, M.A., C.A. Scorer and J.J. Clare. 1992. Foreign gene expression in yeast: a review. Yeast 8:423-488.

143.Roude, W. 1997. From benchtop to bedside. Science 278:1036-1040.

144.Saez-Llorens, X., E. Castano, D. Null, J. Steichen, P.J. Sanchez, O. Ramilo, F.H. Top, Jr. and E. Connor. 1998. Safety and pharmacokinetics of an intramuscular humanized monoclonal antibody to respiratory syncytial virus in premature infants and infants with bronchopulmonary dysplasia. The MEDI-493 Study Group. Pediatr. Infect. Dis. J. 17:787-791.

145.Sánchez, L., M. Ayala, F. Freyre, I. Pedroso, H. Bell, V. Falcón and J.V. Gavilondo. 1999. High cytoplasmic expression in E. coli, purification, and in vitro refolding of a single chain Fv antibody fragment against the hepatitis B surface antigen. J. Biotechnol. 72:13-20.

146.Saragovi, H.U., D. Fitzpatrick, A. Raktabutr, H. Nakanishi, M. Kahn and M. Greene. 1991. Design and sythesis of a mimetic from an antibody complementarity-determining region. Science 253:792-795.

147.Sblattero, D. and A. Bradbury. 2000. Exploiting recombination in single bacteria to make large phage antibody libraries. Nat. Biotechnol. 18:75-80.

148.Schaffitzel, C., J. Hanes, L. Jermutus and A. Plückthun. 1999. Ribosome display: an in vitro method for selection and evolution of antibodies from libraries. J. Immunol. Methods 231:119-135.

149.Schultz, P.G. and R.A. Lerner. 1995. From molecular diversity to catalysis: lessons from the immune system. Science 269:1835-1842.

150.Sensel, M.G., M.J. Coloma, E.T. Harvill, S.U. Shin, R.I. Smith and S.L. Morrison. 1997. Engineering novel antibody molecules. Chem. Immunol. 65:129-158.

151.Sharon, J., M.L. Geffer, T. Manser, S.L. Morrison and V.T. Oi. 1984. Expression of a chimeric $\mathrm{V}_{\mathrm{HCk}}$ protein in mouse myeloma cells. Nature 309:364-367.

152.Shield, C.F., R.J. Jacobs, S. Wyant and A. Das. 1996. A cost-effectiveness analysis of OKT3 induction therapy in cadaveric kidney transplantation. Am. J. Kidney Dis. 27:855864.

153.Skerra, A. and A. Plückthun. 1988. Assembly of a functional immunoglobulin Fv fragment in Escherichia coli. Science 240:10381041.

154.Skerra, A., I. Pfitzinger and A. Plückthun. 1991. The functional expression of antibody Fv fragments in Escherichia coli: improved vectors and a generally applicable purification technique. Bio/Technology 9:273-277.

155.Slade, H.B. 1994. Human immunoglobulins for intravenous use and hepatitis C viral transmission. Clin. Diag. Lab. Immunol. 1:613619.

156.Thompson, K.M. 1988. Human monoclonal antibodies. Immunol. Today 9:113-117.
157.Tomlinson, I.M., G. Walker, J.D. Marks, M.B. Llewelyn and G. Winter. 1992. The repertoire of human germline $\mathrm{V}_{\mathrm{H}}$ sequences reveals about fifty groups of $\mathrm{V}_{\mathrm{H}}$ segments with different hypervariable loops. J. Mol. Biol. 227:776-798.

158.Vaughan, T.J., A.J. Williams, K. Pritchard, J.K. Osbourn, A.R. Pope, J.C. Earnshaw, J. McCafferty, R.A. Hodits, J. Wilton and K.S. Johnson. 1996. Human antibodies with sub-nanomolar affinities isolated from a large non-immunized phage display library. Nat. Biotechnol. 14:309-314.

159.Verhoeyen, M., C. Milstein and G. Winter. 1988. Reshaping human antibodies: grafting an anti-lysozyme activity. Science 239:10981104.

160.von Behring, E. and S. Kitasato. 1890. Ueber Zustandekommen der Diphtherie-Immunitat und der Tetanus-Immunitat bei Thieren. S. Dtsch. Med. Wochenschr. 16:1113-1116.

161. Waterhouse, P., A. Griffiths, K. Johnson and G. Winter. 1993. Combinatorial infection and in vivo recombination: a strategy for making large phage antibody repertoires. $\mathrm{Nu}-$ cleic Acids Res. 21:2265-2266.

162.Weiner, L.M. 1999. Monoclonal antibody therapy of cancer. Semin. Oncol. 26:43-51.

163.Weisman, L.E., D.F. Cruess and G.W. Fischer. 1994. Opsonic activity of commercially available standard intravenous immunoglobulin preparations. Pediatr. Infect. Dis. J. 13:1122-1125.

164.Williams, W.V., T. Kieber-Emmons, J. VonFeldt, M.I. Greene and D.B. Weiner. 1991. Design of bioactive peptides based on antibody hypervariable region structures. J. Biol. Chem. 266:5182-5190.

165.Winter, G. 1993 (issued). Recombinant altered antibodies and methods of making altered antibodies. US5225539.

166.Wood, C.R., M.A. Boss, J.H. Kenten, J.E. Calvert and N.A. Roberts. 1985. The synthesis and in vivo assembly of functional antibodies in yeast. Nature 314:446-447.

167.Woodle, E.S., D. Xu, R.A. Zivin, J. Auger, J. Charette, R. O'Laughlin, D. Peace, L.K. Jollife et al. 1999. Phase I trial of a humanized, Fc receptor nonbinding OKT3 antibody, huOKT3gamma1(Ala-Ala) in the treatment of acute renal allograft rejection. Transplantation 68:608-616.

168.Xiong, S., M. Gerloni and M. Zanetti. 1997. Engineering vaccines with heterologous B and $\mathrm{T}$ cell epitopes using immunoglobulin genes. Nat. Biotechnol. 15:882-886.

169.Yang, X.D., X.C. Jia, J.R. Corvalan, P. Wang, C.G. Davis and A. Jacobovits. 1999. Eradication of established tumors by a fully human monoclonal antibody to the epidermal growth factor receptor without concomitant chemotherapy. Cancer Res. 59:1236-1243.

Address correspondence to:

Dr. James W. Larrick

Palo Alto Institute of Molecular Medicine 2462 Wyandotte St.

Mountain View, CA 94043 USA

e-mail:jwlarrick@aol.com 
Representative Antibodies in Clinical Evaluation

\begin{tabular}{|c|c|c|}
\hline Institution/Company & Antibodies & Characteristics/Application (in order) \\
\hline \multicolumn{3}{|l|}{ CANCER } \\
\hline Ixsys/Scripps & Vitaxin ${ }^{\mathrm{TM}}$ & MAb against $\alpha v \beta 3$ integrin. Cancers. \\
\hline Coulter Pharm. Inc. & Anti-BI & Mouse MAb anti-B1 antigen, coupled to ${ }^{131}$ I. B cell lymphoma. \\
\hline $\mathrm{NCl} / \mathrm{NIH}$, Bethesda & $\begin{array}{l}\text { Anti-Tac Fv- } \\
\text { PE38, LMB-7, } \\
\text { Anti-transferrin } \\
\text { receptor, Ch14.18 }\end{array}$ & $\begin{array}{l}\text { 1. scFv fragment anti-Tac receptor, genetically coupled to } \\
\text { Pseudomonas toxin domains (PE38). Leukemia/lymphoma. } \\
\text { 2. scFv fragment against a tumor associated glycoprotein, } \\
\text { genetically coupled to Pseudomonas toxin domains (PE38). } \\
\text { Colon and breast cancers, other advanced stage solid tumors. } \\
\text { 3. Advanced refractory solid tumors. 4. Chimeric anti-melanoma } \\
\text { antibody. Melanoma and neuroblastoma. }\end{array}$ \\
\hline NeoRx/Dupont & Verluma ${ }^{\mathrm{TM}}$ & MAb for imaging in small-cell and non-small-cell lung tumors. \\
\hline $\begin{array}{l}\text { Janssen Pharmaceutica/ } \\
\text { NeoRx }\end{array}$ & Avicidin ${ }^{\circledR}$ & MAb conjugate. Colorectal, lung, prostate cancers. \\
\hline NeoRx & NR-LU-10 & $\begin{array}{l}\text { In situ radiotherapy with } 90 \mathrm{Y} \text { indirectly labeled pan carcinoma } \\
\text { antibody. Colon metastases, ovarian cancer, prostate cancer. }\end{array}$ \\
\hline Perlmmune & Anti-colon cancer & Human MAb. Colorectal cancer imaging. \\
\hline Genentech & Anti-VEGF & Humanized antibody. Cancers. \\
\hline Chiron & Bispecific antibody & Cancer. \\
\hline Wyeth-Ayerst Labs & CMB-401, CMA-676 & 1. Ovarian cancer. 2. Relapsed acute myelogenous leukemia. \\
\hline $\begin{array}{l}\text { Memorial Sloan- } \\
\text { Kettering, NY }\end{array}$ & hB72.3 & $\begin{array}{l}\text { Humanized B72.3 Ab against the TAG72 tumor associated } \\
\text { glycoprotein. Breast cancer. }\end{array}$ \\
\hline Centocor/Glaxo & $\begin{array}{l}\text { Panorex } \\
\text { edrecolomab }\end{array}$ & $\begin{array}{l}\text { Chimeric } 17-1 \mathrm{~A} \text { anti Lewis y Ab. Adjuvant therapy for metastatic } \\
\text { colorectal cancer. }\end{array}$ \\
\hline Cytel/Upjohn & CY1748 & Humanized anti-P selectin Ab. Inflammation and cancer. \\
\hline $\begin{array}{l}\text { Royal Free Hospital } \\
\text { Sch. Medicine, London }\end{array}$ & MFE-23 & $\begin{array}{l}\text { scFv fragment against the B3 CEA domain obtained } \\
\text { from a phage library. Radioimaging in colon carcinoma. }\end{array}$ \\
\hline $\begin{array}{l}\text { Contra Costa Cancer Center, } \\
\text { California }\end{array}$ & HuBrE.3 & $\begin{array}{l}90 Y \text { indirectly labeled humanized anti mucin } \mathrm{Ab} \text {. In situ } \\
\text { radiotherapy in breast cancer. }\end{array}$ \\
\hline ImClone Systems & C225, BEC-2 & $\begin{array}{l}\text { 1. Chimeric anti EGF-receptor Ab. Many EGF receptor-positive } \\
\text { cancers. } 2 \text {. Anti-idiotypic MAb that mimics the GD3 ganglioside } \\
\text { found in some tumor cells. Small cell lung cancer. }\end{array}$ \\
\hline $\begin{array}{l}\text { CIMAB SA, Havana/York } \\
\text { Medical }\end{array}$ & $\begin{array}{l}\text { ior-R3, ior-r3hum, } \\
\text { ior-c5 }\end{array}$ & $\begin{array}{l}\text { 1. Anti EGF-receptor MAb. EGF receptor-positive cancers in } \\
\text { combination with radiotherapy. 1. Humanized anti EGF-receptor } \\
\text { antibody. EGF receptor-positive cancers. } 3.99 \text { Tc-labeled mouse } \\
\text { MAb against carcinoma-associated glycoprotein. Recurrent and } \\
\text { metastatic colorectal carcinoma imaging. }\end{array}$ \\
\hline ImmunoGen & $\begin{array}{l}\text { Oncolysin } \mathrm{B}^{\mathrm{TM}} \\
\text { C242-DM1 }\end{array}$ & $\begin{array}{l}\text { 1. Immunotoxin composed by a MAb against lymphoma cells, } \\
\text { coupled to a very potent proprietary drug. } 2 \text {. MAb against a colon } \\
\text { cancer antigen, coupled to a very potent proprietary drug. }\end{array}$ \\
\hline Bristol-Myers Squibb & BR96 & $\begin{array}{l}\text { Conjugate between a genetically engineered improved MAb } \\
\text { against the Lewis y antigen and doxorubicin. Carcinomas. }\end{array}$ \\
\hline $\begin{array}{l}\text { Techniclone Int. and } \\
\text { Techniclone Int/Alpha } \\
\text { Therapeutic }\end{array}$ & $\begin{array}{l}\text { ChTNT-1/b, } \\
1311-\text { ChTNT-1/b, } \\
\text { Oncolym }\end{array}$ & $\begin{array}{l}\text { 1. Chimeric Ab. Non-Hodgkin's B cell lymphoma, solid tumors. } 2 . \\
\text { Radiolabeled chimeric Ab. Malignant glioma. 3. Chimeric anti- } \\
\text { HLA-DR Ab radiolabeled with 131I. Non-Hodgkin's lymphoma. }\end{array}$ \\
\hline Novartis & Anti-idiotype MAb & Cancers. \\
\hline IDEC Pharm. & $\begin{array}{l}\text { IDEC-Y2B8, } \\
\text { IDEC-InB8 }\end{array}$ & $\begin{array}{l}\text { 1. Non-Hodgkin's B-cell lymphoma. Combination with Rituximab }{ }^{\circledR} \text {. } \\
\text { 2. Non-Hodgkin's B-cell lymphoma. }\end{array}$ \\
\hline
\end{tabular}


Representative Antibodies in Clinical Evaluation (continued)

\begin{tabular}{|c|c|c|}
\hline Institution/Company & Antibodies & Characteristics/Application (in order) \\
\hline Neoprobe & RIGScan ${ }^{\circledR}$ CR49 & MAb for colorectal cancer imaging. Application submitted. \\
\hline Cytogen & $\begin{array}{l}\text { OncoRad }{ }^{\circledR} \text { PR CYT- } \\
\text { 356-Y-90, OncoScint }{ }^{\circledR}\end{array}$ & $\begin{array}{l}\text { 1. In situ radiotherapy with } 90 \mathrm{Y} \text { labeled pan carcinoma antibody. } \\
\text { Prostate cancer. } 2 \text {. Detection, staging and followup of breast cancer. }\end{array}$ \\
\hline Medarex & $\begin{array}{l}\text { MDX-447, } \\
\text { MDX-H210, MDX-220 }\end{array}$ & $\begin{array}{l}\text { 1. Bispecific Ab. Head and neck, renal cancers. 2. Bispecific Ab. } \\
\text { Breast, colorectal, kidney, ovarian, prostate. 3. Bispecific Ab. Cancers. }\end{array}$ \\
\hline Immunomedics & $\begin{array}{l}\text { CEA-Cide }{ }^{\mathrm{TM}}, \text { hMN14, } \\
\text { CEA-Scan } \\
\text { LymphoScan }^{\mathrm{TM}} \\
\text { Lymphocide }^{\mathrm{TM}} \\
\text { AFP-Scan } \\
\text { ImmuRAIT-CEA, } \\
\text { ImmuRAIT-LL2 }\end{array}$ & $\begin{array}{l}\text { 1. Humanized anti-CEA Ab. CEA-positive cancers. } 2 .{ }^{99} \mathrm{mTc} \text { labeled } \\
\text { anti-CEA MAb. Breast and lung cancer. 3. Staging and residual } \\
\text { disease in non-Hodgkin's B-cell lymphoma. } 4.99 \mathrm{mT} \text { labeled } \\
\text { anti-CD22 humanized Ab. Non-Hodgkin's B lymphoma. } 5.99 \mathrm{mTc} \\
\text { labeled Fab fragment against germ cells. Liver and germ cell } \\
\text { cancer staging. 6. Anti-CEA } 131 \mathrm{I} \text { labeled MAb. Colorectal cancer. } \\
\text { 7. }{ }^{131} \mathrm{I} \text { labeled MAb. Non-Hodgkin's B lymphoma. }\end{array}$ \\
\hline Millenium & Campath 1 LDP-03 & Anti-CD52 humanized Ab. Chronic lymphocytic leukemia. \\
\hline $\begin{array}{l}\text { Protein Design Labs/ } \\
\text { Kanebo, and Protein } \\
\text { Design Labs / } \\
\text { Hoffmann-La Roche }\end{array}$ & $\begin{array}{l}\text { SMART } \\
\text { SM M195, } \\
\text { SMARTM1D10, } \\
\text { Zenapax }^{\circledR}\end{array}$ & $\begin{array}{l}\text { 1. Anti-CD33 humanized Ab. Acute myeloid leukemia Acute } \\
\text { promyelocytic leukemia . } 2 \text {. Anti-HLA humanized Ab Non- } \\
\text { Hodgkin's lymphoma. } 3 \text {. Anti-CD25 humanized Ab. Advanced } \\
\text { myeloid leukemia. Certain blood cancers. }\end{array}$ \\
\hline Altarex & OvaRex & Anti-CA125 MAb. Ovarian cancer. \\
\hline ICOS & Anti-ICAM 3 & Humanized Ab. Cancer treatment. \\
\hline \multicolumn{3}{|c|}{ AUTOIMMUNE DISORDERS } \\
\hline Celltech/Bayer & CDP 571 & $\begin{array}{l}\text { Humanized anti-TNF alpha Ab. Crohn's disease and ulcerative } \\
\text { colitis. Rheumatoid arthritis. }\end{array}$ \\
\hline Protein Design Labs & SMART ${ }^{\mathrm{TM}}$ anti-CD3 & Humanized anti-CD3 Ab. Autoimmune diseases. \\
\hline $\begin{array}{l}\text { IDEC/Smith Kline, } \\
\text { IDEC, IDEC/ Glaxo/ } \\
\text { Smith Kline }\end{array}$ & $\begin{array}{l}\text { Clenoliximab, } \\
\text { IDEC-131, } \\
\text { IDEC } 151\end{array}$ & $\begin{array}{l}\text { 1. Humanized Ab. Rheumatoid arthritis. 2. Humanized } \\
\text { anti-CD } 40 \text { L Ab. Systemic lupus erythematosus. Multiple } \\
\text { Sclerosis. 3. Anti-CD4 primatized Ab. Rheumatoid arthritis. }\end{array}$ \\
\hline Biogen & Anti-CD40L & Humanized Ab. Lupus, immune thrombocytopenic purpura. \\
\hline $\begin{array}{l}\text { Alexion } \\
\text { Pharmaceuticals }\end{array}$ & h5G1.1 & $\begin{array}{l}\text { Humanized anti-C5 Ab. Treatment of collagen-induced arthritis, glo- } \\
\text { merulonephritis. Rheumatoid arthritis. Systemic lupus erythematosus. }\end{array}$ \\
\hline Ortho Biotech & Orthoclone OKT4 & Anti-CD4 mouse MAb. CD4 mediated autoimmune diseases. \\
\hline Millenium & LDP-02 & Anti- $\alpha 4 \beta 7$ humanized Ab. Ulcerative colitis. \\
\hline $\begin{array}{l}\text { Cambridge Antibody } \\
\text { Technology/BASF }\end{array}$ & J695 & $\begin{array}{l}\text { Anti-IL12 human Ab from phage library. Rheumatoid arthritis. } \\
\text { Crohn's disease. }\end{array}$ \\
\hline $\begin{array}{l}\text { Cambridge Antibody } \\
\text { Technology/BASF }\end{array}$ & D2E7 & $\begin{array}{l}\text { Anti-TNF alpha human Ab from phage library. Rheumatoid } \\
\text { arthritis. }\end{array}$ \\
\hline $\begin{array}{l}\text { Medarex/Centeon, } \\
\text { Medarex/Eisai/ } \\
\text { Genmab }\end{array}$ & $\begin{array}{l}\text { MDX } 33 \\
\text { MDX CD4 }\end{array}$ & $\begin{array}{l}\text { 1. Anti-sCD64 (FcR) human MAb from transgenic mice. } \\
\text { Autoimmune hematological disorders. } 2 \text {. Anti-CD4 human MAb } \\
\text { from transgenic mice. Rheumatoid arthritis. }\end{array}$ \\
\hline \multicolumn{3}{|c|}{ HEART/VASCULAR DISEASE AND BLOOD DISORDERS } \\
\hline Repligen & h60.1 & $\begin{array}{l}\text { Humanized anti CD11B Ab. Ischemia /reperfussion in } \\
\text { thoracoabdominal aneurysm. }\end{array}$ \\
\hline Alexion Pharm. & h5G1.1 & $\begin{array}{l}\text { Humanized anti C5 scFv. Stroke, myocardial infarction and } \\
\text { surgical trauma. }\end{array}$ \\
\hline Genentech & Anti-CD18 & Anti-CD18 humanized Fab'2. Acute myocardial infarction. \\
\hline Boehringer Ingelheim & BIRR-1 & Anti-ICAM 1 MAb. Prevention of reperfussion damage. \\
\hline
\end{tabular}


Representative Antibodies in Clinical Evaluation (continued)

\begin{tabular}{|c|c|c|}
\hline Institution/Company & Antibodies & Characteristics/Application (in order) \\
\hline Centocor & Capiscint, ReoPro ${ }^{\circledR}$ & $\begin{array}{l}\text { 1. Atherosclerotic plaque imaging agent. 2. Chimeric anti-gpllbllla } \\
\text { Ab. Unstable angina. Acute myocardial infarction. }\end{array}$ \\
\hline American Biogenetic Sciences & MH1-Fab & Fab. In vivo imaging cardiovascular thrombosis. \\
\hline ICOS & nHu23F2G & $\begin{array}{l}\text { Humanized Ab anti-adhesion molecules. Myocardial infarction. } \\
\text { Hemorragic shock. Ischemic stroke. }\end{array}$ \\
\hline Biogen & VL4-A integrin & Humanized Ab. Artheriopathy. \\
\hline Centocor & Corsevin ${ }^{\mathrm{TM}} \mathrm{M}$ & $\begin{array}{l}\text { Anti-Factor VII -Fab or imaging. Disseminated intravascular } \\
\text { coagulation. }\end{array}$ \\
\hline \multicolumn{3}{|l|}{ NEUROLOGIC DISORDERS } \\
\hline Boehringer Ingelheim & Enlimomab & Anti-ICAM 1 Ab. Stroke. \\
\hline ICOS & nHu23F2G & Humanized Ab anti-adhesion molecules. Multiple sclerosis. \\
\hline Athena Neurosciences & Antegren ${ }^{\mathrm{TM}}$ & Anti-LMF humanized antibody. Multiple sclerosis flares. \\
\hline Millenium & LDP-01 & Humanized beta 2 integrin. Stroke. \\
\hline $\begin{array}{l}\text { Protein Design Labs/ } \\
\text { Hoffmann-La Roche }\end{array}$ & $\begin{array}{l}\text { Zenapax }^{\circledR} \\
\text { daclizumab }\end{array}$ & Anti-CD25 humanized Ab. Tropical spastic paraparesis. \\
\hline Centocor & ReoPro ${ }^{\circledR}$ abciximab & Chimeric anti gpllbllla Ab. Stroke. \\
\hline IDEC Pharm & IDEC 131 & Humanized anti-CD40L Ab. Multiple sclerosis. \\
\hline $\begin{array}{l}\text { Cambridge Antibody } \\
\text { Technology/BASF }\end{array}$ & $\mathrm{J} 695$ & Anti-IL12 human Ab from phage library. Multiple sclerosis. \\
\hline T Cell Sciences & ATM027 & Humanized antibody. Multiple sclerosis. \\
\hline \multicolumn{3}{|l|}{ INFLAMMATION } \\
\hline Cell Genesys & Anti-selectins & Humanized Abs. Inflammatory disease. \\
\hline ICOS & nHu23F2G & Humanized Ab anti-adhesion molecules. Inflammatory disease \\
\hline Protein Design Labs & $\begin{array}{l}\text { Anti-E/P and } L \\
\text { selectins }\end{array}$ & $\begin{array}{l}\text { Humanized antibodies. Trauma, stroke, digestive tract } \\
\text { inflammatory diseases, and reperfussion. }\end{array}$ \\
\hline Boehringer Ingelheim & Anti-ICAM-1 & Murine anti-ICAM 1 MAb. Burns. \\
\hline \multicolumn{3}{|l|}{ TRANSPLANTATION } \\
\hline Boehringer Ingelheim & Anti-ICAM-1 & Murine anti-ICAM 1 MAb. Phase II/III for kidney transplant rejection. \\
\hline BioTransplant/ Medlmmune & $\begin{array}{l}\text { BTI-322, } \\
\text { T10B9 }\end{array}$ & $\begin{array}{l}\text { 1. Anti-CD2 rat MAb. Allograft rejection. 2. Anti-T cell receptor. } \\
\text { Allograft rejection. }\end{array}$ \\
\hline Medlmmune & $\begin{array}{l}\text { MEDI-507, } \\
\text { MEDI-500 }\end{array}$ & $\begin{array}{l}\text { 1. Anti-CD2 humanized Ab. GVHD. Acute kidney transplant } \\
\text { rejection. 2. Anti-TCR } \alpha \beta \text { humanized Ab. GVHD. }\end{array}$ \\
\hline Sandoz & Anti-CD25 & Humanized Ab. Allograft rejection. \\
\hline Abgenix & $A B X-C B L$ & $\begin{array}{l}\text { Anti-CD147(CBL) human MAb from transgenic mice. } \\
\text { GVHD. Allograft rejection. }\end{array}$ \\
\hline Millenium & LDP-01 & Humanized anti-beta 2 integrin. Kidney transplantation. \\
\hline Bristol-Myers & CTLA-4 & Immunoligand with anti-CD28 activity. Allograft rejection. \\
\hline $\begin{array}{l}\text { Protein Design Labs, } \\
\text { Protein Design Labs/ } \\
\text { Hoffmann-La Roche }\end{array}$ & $\begin{array}{l}\text { SMART }{ }^{\mathrm{TM}} \text { anti-CD3 } \\
\text { Zenapax }{ }^{\circledR} \\
\text { daclizumab }\end{array}$ & $\begin{array}{l}\text { 1. Humanized anti-CD3 Ab. Transplantation. 2. Humanized anti } \\
\text { CD25 Ab. Liver transplant. Pediatric kidney transplant. } \\
\text { Kidney transplant rejection with cyclosporine elimination. }\end{array}$ \\
\hline $\begin{array}{l}\text { Ortho Biotec and } \\
\text { Ortho/Novum }\end{array}$ & OKT4A, hOKT-4A & $\begin{array}{l}\text { 1. Anti-CD4 mouse MAb. Prophylaxis of allograft rejection. 2. Human- } \\
\text { ized version of the OKT4 anti-CD4 MAb. Allograft rejection. }\end{array}$ \\
\hline
\end{tabular}


Representative Antibodies in Clinical Evaluation (continued)

\begin{tabular}{|c|c|c|}
\hline Institution/Company & Antibodies & Characteristics/Application (in order) \\
\hline Pasteur Merieux/Immunotech & Anti-LFA1 & Anti-CD18 murine MAb. Allograft rejection. \\
\hline Biogen & Antova & Humanized anti-CD40L Ab. Allograft rejection. \\
\hline \multicolumn{3}{|l|}{ SKIN DISORDERS } \\
\hline Genentech & hu1124 & Anti-CD11a humanized Ab. Moderate to severe psoriasis. \\
\hline ICOS & ICM3 & Anti-ICAM 3 Ab. Psoriasis. \\
\hline CIMAB SA, Havana & ior- +1 & Anti-CD6 MAb. Psoriasis. \\
\hline Medlmmune & MEDI-507 & Anti-CD2 humanized Ab. Psoriasis. \\
\hline Abgenix & ABX-IL8 & Anti IL8 human MAb from transgenic mice. Psoriasis. \\
\hline Celltech & CDP-850 & E-selectin humanized Ab. Psoriasis. \\
\hline IDEC/Mitsubishi & IDEC-114 & Anti-CD80 primatized Ab. Psoriasis. \\
\hline $\begin{array}{l}\text { Cambridge Antibody } \\
\text { Technology }\end{array}$ & CAT 192 & $\begin{array}{l}\text { Anti-TGFB1 fully human Ab derived from phage library. } \\
\text { Fibrotic disease. Scarring. }\end{array}$ \\
\hline $\begin{array}{l}\text { Protein Design Labs, } \\
\text { Protein Design Labs/ } \\
\text { Hoffmann-La Roche }\end{array}$ & $\begin{array}{l}\text { SMART }{ }^{\mathrm{TM}} \text { anti-CD3 } \\
\text { Zenapax }{ }^{\circledR} \\
\text { daclizumab }\end{array}$ & $\begin{array}{l}\text { 1. Humanized anti-CD3 Ab. Psoriasis. 2. Humanized } \\
\text { Anti-CD25 Ab. Psoriasis. }\end{array}$ \\
\hline \multicolumn{3}{|l|}{ INFECTIOUS DISEASES } \\
\hline Knoll Pharm./BASF & MAK $195 \mathrm{~F}$ & Anti TNF alpha murine Fab'2. Treatment of sepsis. \\
\hline Immunomedics & LeukoScan ${ }^{\circledR}$ & Imaging of osteomyelitis, infected prosthesis, appendicitis. \\
\hline $\begin{array}{l}\text { Protein Design Labs, } \\
\text { Protein Design Labs/ } \\
\text { Novartis }\end{array}$ & $\begin{array}{l}\text { ProtovirTM } \\
\text { SDZ OST } 577 \\
\text { SDZ MSL } 109\end{array}$ & $\begin{array}{l}\text { 1. Anti-CMV humanized Ab. Infection in liver transplantation. } \\
\text { 2. Anti-HBsAg human MAb. Infection in liver transplantation. } \\
\text { 3. Anti-HBsAg human MAb. Infection. }\end{array}$ \\
\hline Progenics/Genzyme Transgenics & PRO 542 & Anti- gp120 HIV humanized Ab. Neutralizing. \\
\hline Peptide Therap. & HNK20 & Anti RSV Fgp murine IgA MAb. Respiratory infection. \\
\hline Planet Biotechnology & CaroRx $x^{\mathrm{TM}}$ & $\begin{array}{l}\text { Chimeric slgA anti-Strepococcus mutans produced in transgenic } \\
\text { tobacco. Complementary treatment for the prevention of caries. }\end{array}$ \\
\hline \multicolumn{3}{|c|}{ RESPIRATORY AND ALLERGIC DISORDERS } \\
\hline Biogen & Anti-VL4-A integrin & Humanized antibody. Asthma. \\
\hline Genentech/Tannox/Novartis & rhuMabE25 & Humanized anti IgE Ab. hay fever. Allergic asthma. Allergic rhinitis. \\
\hline IDEC Pharm & IDEC-152 & Anti-CD23 primatized Ab. Allergy. Asthma. \\
\hline Glaxo/Smith Kline & SB-240563, & $\begin{array}{l}\text { 1. Anti-IL5 humanized Ab. Allergy. Asthma. } \\
\text { 2. Anti-IL4 humanized SB-240683 Ab Allergy. Asthma. }\end{array}$ \\
\hline Celltech/Schering & SCH 55700 & Anti-IL5 humanized Ab. Allergy. Asthma. \\
\hline \multicolumn{3}{|l|}{ MISCELLANEOUS } \\
\hline $\begin{array}{l}\text { Cambridge Antibody } \\
\text { Technology }\end{array}$ & CAT 152 & $\begin{array}{l}\text { Anti-TGFB2 fully human Ab derived from phage } \\
\text { library. Glaucoma surgery. }\end{array}$ \\
\hline Medarex & MDX-RA & Immunotoxin. Prevention of secondary cataracts. \\
\hline ICOS & $\mathrm{IC} 14$ & Anti-CD14 Ab. Toxic shock. \\
\hline
\end{tabular}

